\title{
Impacts of detrital nano- and micro-scale particles (dNP) on contaminant dynamics in a coal mine AMD treatment system
}

\author{
Liliana Lefticariu $^{1,2} *$, Stephen R. Sutton ${ }^{3,4}$, Kelly S. Bender ${ }^{5}$, Mihai Lefticariu ${ }^{6}$, Martin Pentrak ${ }^{7}$ \\ ${ }^{1}$ Department of Geology, Southern Illinois University, Carbondale, IL 62901, USA. \\ ${ }^{2}$ Environmental Resources and Policy Program, Southern Illinois University, Carbondale, IL 62901, USA. \\ ${ }^{3}$ Department of Geophysical Sciences, University of Chicago, Chicago, IL 60637 \\ ${ }^{4}$ Center for Advanced Radiation Sources, University of Chicago, Chicago, IL 60637 \\ ${ }^{5}$ Department of Microbiology, Southern Illinois University, Carbondale, IL 62901, USA. \\ ${ }^{6}$ Mass Spectrometry Facility, Southern Illinois University, Carbondale, IL 62901, USA. \\ ${ }^{7}$ Department of Natural Resources and Environmental Sciences, University of Illinois at Urbana-Champaign, \\ Urbana, IL 61801, USA.
}

*Corresponding author: email lefticar@siu.edu, phone: 618453 7373; fax: 6184537393

\section{Submission date: May, 2016}

Revised: September, 2016

Keywords: acid mine drainage, bioremediation, nanoparticles, clay minerals, coal mining; Detrital nano-and micro-scale particles (dNP); Neoformed nano-and micro-scale particles (nNP) 


\section{ABSTRACT}

Pollutants in acid mine drainage (AMD) are usually sequestered in neoformed nano- and micro-scale particles (nNP) through precipitation, co-precipitation, and sorption. Subsequent biogeochemical processes may control nNP stability and thus long-term contaminant immobilization. Mineralogical, chemical, and microbiological data collected from sediments accumulated over a six-year period in a coal-mine AMD treatment system were used to identify the pathways of contaminant dynamics. We present evidence that detrital nano- and micronscale particles (nDP), composed mostly of clay minerals originating from the partial weathering of coal-mine waste, mediated biogeochemical processes that catalyzed AMD contaminant (1) immobilization by facilitating heterogeneous nucleation and growth of nNP in oxic zones, and (2) remobilization by promoting phase transformation and reductive dissolution of nNP in anoxic zones.

We found that nDP were relatively stable under acidic conditions and estimated a nDP content of $\sim 0.1 \mathrm{~g} / \mathrm{L}$ in the influent AMD. In the AMD sediments, the initial nNP precipitates were schwertmannite and poorly crystalline goethite, which transformed to well-crystallized goethite, the primary nNP repository. Subsequent reductive dissolution of nNP resulted in the remobilization of up to $98 \%$ of $\mathrm{S}$ and $95 \%$ of Fe accompanied by the formation of a compact nDP layer. Effective treatment of pollutants could be enhanced by better understanding the complex, dynamic role nDP play in mediating biogeochemical processes and contaminant dynamics at coal-mine impacted sites. 


\section{Introduction}

Over the past century, extensive surface and underground coal mining in the Illinois Basin and other regions of the US has left a legacy of a large number of abandoned sites, many of which produce drainages that are acidic and have high contents of $\mathrm{S}, \mathrm{Fe}, \mathrm{Al}$, and other environmentally relevant pollutants (i.e., $\mathrm{As}, \mathrm{Cd}, \mathrm{Cu}, \mathrm{Hg}, \mathrm{Ni}, \mathrm{Mn}, \mathrm{Se}, \mathrm{Pb}$, and $\mathrm{Zn}$ ) (Cravotta, C.A., 2008; Blowes et al., 2014; Lefticariu et al., 2015). Mitigating the environmental impact of acid mine drainages (AMD) is dependent on deciphering the highly complex interplays between the physical and biochemical processes associated with their mobilization, transport, sequestration, and overall long-term fate in natural and engineered systems (Küsel 2003; Gagliano et al., 2004; Burgos et al., 2012; DiLoreto et al., 2016).

The formation of Fe(III)-rich phases, which in coal mining-impacted areas form a yelloworange deposit colloquially known as "yellow boy", has been identified as a feasible bioremediation strategy for permanently immobilizing contaminants through precipitation, coprecipitation, sorption, and surface complexation (Waychunas et al., 2005; Hochella et al., 2008; French et al., 2012). These precipitates, typically found as neoformed nano- and microscale particles (nNP), include amorphous and crystalline phases such as schwertmannite [ideal formula $\mathrm{Fe}_{8} \mathrm{O}_{8}(\mathrm{OH})_{6} \mathrm{SO}_{4}$; Bighametal.,1996], goethite $(\alpha-\mathrm{FeOOH})$, lepidocrocite $(\gamma-\mathrm{FeOOH})$, and jarosite [e.g., $\mathrm{KFe}_{3}\left(\mathrm{SO}_{4}\right)_{2}(\mathrm{OH})_{6}$ ] (Bigham et al., 1996; Caraballo et al., 2013; Yang et al., 2015). The unique properties of nNP, including small size, high surface area, and high reactivity allow them to dominate geochemical processes, even when present in minute amounts (Hochella et al. 2008; Navrotsky et al., 2008).

Microorganisms play key roles in Fe and S cycles in low-pH environments due to their ability to adapt to a remarkable range of extreme conditions (Sánchez-Andrea et al., 2011; Johnson et al., 2012). In AMD-impacted settings, the microbial communities are very active in redox transformation of Fe and as such various microorganisms can catalyze the dissimilatory oxidation of Fe(II) (Fe-oxidizing bacteria-FeOB), or reduction of Fe(III) (Fe-reducing bacteriaFeOB), or can do both depending on the prevailing environmental conditions (Lu et al., 2010; Johnson et al., 2012). Remarkably, the iron-metabolizing acidophiles are highly diverse in low- 
$\mathrm{pH}$ settings, occurring in the domain Bacteria within the Proteobacteria, Nitrospirae, Firmicutes, Actinobacteria, and Acidobacteria phyla, and in the domain Archaea within the Crenarchaeota and Euryarchaeota phyla (Baker and Banfield, 2003; Johnson et al., 2012), and often establish complex interspecies interactions to better cope with harsh acidic conditions (Comolli and Banfield, 2014). At AMD-impacted sites, acidophilic microbial assemblages vary in their response to temperature, organic carbon, $\mathrm{pH}$, and geochemical composition of the mine drainages as well as the local hydrodynamic conditions (Küsel et al., 2008; Burns et al., 2012). Acidophilic FeOB are instrumental in Fe(II) oxidation to Fe(III), which subsequently hydrolyzes and precipitates a wide range of nNP, thus contributing to Fe immobilization (Küsel, K., 2003; Lu et al., 2013; Lefticariu et al., 2015). Substantial amounts of other AMD contaminants (e.g., heavy metals) are also sequestered by nNP and as such their formation becomes important in controlling pollutants in watershed affected by mining activities (Borch et al., 2009).

Complicating the accurate prediction of contaminant sequestration are the potential transformations of nNP due to both their aforementioned physiochemical properties (Navrotsky et al., 2008) as well as the strong influence of the redox chemistry and reaction kinetics that control nNP stability (Cornell and Schwertmann, 1996; Bigham and Nordstrom, 2000; Waychunas et al., 2005; Braunschweig et al., 2013). These transformations can be both abiotic and biologically-mediated and occur predominantly in systems with fluctuating redox conditions (Küsel et al., 2002; Hansel et al., 2003; Roden, 2012). The microbial-mediated reduction of Fe(III) can comprise both aqueous Fe(III), which has a greater solubility in extremely acidic environments and thus is more bioavailable (Johnson et al., 2012), as well as solid Fe(III) phases (Zachara et al., 2002; Küsel et al., 2002; Hansel et al., 2003).

Recent studies have also shown that detrital nano- and micro-scale particles (dNP) can also act as potential vectors of contaminant transport in mining impacted areas (Hudson-Edwards, 2003; Hochella et al., 2005). Especially, many surface water systems have been heavily impacted by the large quantities of dNP released by the active and historic mining activities (Hudson-Edwards, 2016). Increasing attention has been paid to the environmental fate of the metal-bearing dNP originating from mining and mineral processing because they pose a 
significant environmental threat to organisms, plants, and humans that directly or indirectly interact with contaminated waters (Nordstrom et al., 2015; Hudson-Edwards, 2016).

Most research on contaminant transport and sequestration in coal mining impacted watersheds has focused on dissolved constituents and the formation of nNP (Dold, 2003a; Caraballo et al., 2009; Burgos et al., 2012; Lefticariu et al., 2015) and relatively little research has examined the role of dNP in contaminant transport and particularly on the complex interaction between $\mathrm{nNP}$ and dNP in natural systems affected by coal mining. The normal functions of coal mine treatment systems are often impeded by the excessive accumulation of precipitates which can include both nNP and dNP (Lefticariu et al., 2015). Such precipitates can contribute to armoring of the reactive surface areas of the limestone, decreasing permeability and thus affecting the retention time of AMD in the treatment system and consequently reducing the effective lifetime of such engineered system. Therefore, a better understanding of the role of nNP and dNP in the formation of precipitates is critical to understanding the fate and behavior of contaminants in natural systems affected by coal mining as well as for designing more efficient remediation strategies in coal mining impacted areas.

The current study characterizes sediments accumulated over a six-year period in a coalmine AMD treatment system in Southern Illinois using mineralogical, chemical, and microbiological data. Special attention was given to dNP and their relation to nNP so that mechanisms that control AMD contaminant immobilization and transport in natural and engineered systems can be elucidated. In AMD sediments, the dNP, which were dominated by clay minerals originating from the partial weathering of coal mine waste, played a dominant role in biogeochemical processes that controlled AMD contaminant behavior. Depending on environmental conditions, the dNP promoted either contaminant sequestration as dissolved sulfate and ferric iron precipitate as nNP or remobilization through reductive dissolution of nNP. For the studied AMD system, we provide an estimate of the dNP influx from the coal mine waste. A sequence of plausible biogeochemical redox processes that accounts for both $\mathrm{S}$ and $\mathrm{Fe}$ sequestration as nNP and S and Fe remobilization during subsequent diagenetic processes is proposed to explain the coal mine contaminant dynamics in the AMD sediments. To our 
knowledge, this study is the first to report the importance of dNP in contaminant transport in a system impacted by coal mining.

\section{Material and methods}

\subsection{Tab-Simco acid mine drainage treatment system}

Tab-Simco site is an abandoned coal mine located approximately $6 \mathrm{~km}$ SE of Carbondale, Illinois. The site, recognized as one of the highest contaminated sites in the Midwestern U.S., has been producing persistent contaminated drainage for more than 40 years, with the AMD containing notably high average concentrations of dissolved inorganic constituents $\mathrm{S}$ (60 $\mathrm{mM} / \mathrm{L})$, Fe (16 mM/L), Al (7.6 mM/L), Si (1.7 mM/L) and additional environmentally relevant metals (i.e., Mn, V, Cr, Cu, Ni, Zn, Co, and Cd) (Behum et al., 2011; Lefticariu et al., 2015). Two coal seams were mined in the area, namely Murphysboro and Mount Rorah coal members of the Tradewater Formation, which are part of the Pennsylvanian System in the Illinois Basin (Fig. SI-1). Underground coal mining occurred between 1890 and 1955 and was followed by strip mining of both coal seams between 1960 and 1975. The mining activities, which ceased in 1975, left large masses of waste and numerous open underground mine works exposed to weathering. At Tab Simco, the main source of AMD is the acid waters pools formed within the underground mine works. The AMD discharges through a series of seeps into a small tributary that runs north before discharging into the receiving stream, the Sycamore Creek. The reclamation started in 1996 and culminated with the construction of a remediation system designed to treat the coal-generated AMD. The remediation system consists of a sulfatereducing bioreactor cell (Fig. 1a), two aerobic wetlands, and open limestone drains. The TS bioreactor cell was lined with an impermeable liner and comprised, from top to bottom, a > 0.5-meter standing AMD water impoundment, the acid pond (AP), a 2-meter thick organic substrate layer underlying the acid pond, and a 0.3-meter limestone layer (Fig. 1b). The organic substrate layer was composed of $53 \%$ woodchips, $27 \%$ straw mulch, $11 \%$ seasoned compost, and $9 \%$ agricultural ground limestone. A general description of the study area, the mining 
history, and the reclamation efforts can be found in our previous reports (Segid, 2010; Behum et al., 2011).

The influent AMD entered the bioreactor cell at one end then infiltrated the organic substrate layer where though a combination of biological and abiotic processes the AMD was treated and subsequently collected within the limestone layer, where perforated 6" PVC pipes and an AgriDrain water control structure were used to discharge the treated effluent AMD (Fig. 1b). An acid pond formed and grew over time due to the slow infiltration rates of the influent AMD into the organic substrate layer. The bioreactor cell was completed in October 2007 and started to treat AMD soon thereafter (Behum et al., 2011). After 6 years of active operation, decreasing AMD remediation efficiency made the replacement of the organic substrate layer within the bioreactor cell necessary. During the years of operation, active precipitation of AMD contaminants occurred in the acid pond and an uneven sediment layer with an average thickness of $\sim 40 \mathrm{~cm}$ accumulated on top of the organic substrate layer.

\subsection{AMD sediment morphology}

Samples were collected from the Tab Simco bioreactor in July 2013 immediately after the AP was drained and the sediments that had been accumulating on top of the organic substrate over a 6 year period were partially exposed. Sediment thickness varied, from $\sim 30 \mathrm{~cm}$ at the Tab Simco bioreactor inlet to more than $50 \mathrm{~cm}$ in areas adjacent to the bioreactor cell outlet (Fig. 2). The top of the sediments formed a highly uneven surface (Fig. 2a), with a topography characterized by depressions (Fig. 2b) and uplifted small mounds (vents) (Fig. 2c, d). Within the OM, the inhomogeneous distribution of bacterial communities resulted in the formation of isolated compartments from which biologically produced gases were emitted. The upward migration of gases (i.e., $\mathrm{H}_{2} \mathrm{~S}, \mathrm{CO}_{2}$ ) through the organic substrate layer and the newly formed precipitate layer manifested itself as sediment doming and gas vents with location was marked by gas bubbles at the surface of the acid pond. The vent system provided greater hydrological connectivity between the acid pond and the underlying organic substrate layer, thus potentially increasing the transport of not only gasses out of the organic substrate but also of AMD from the acid pond into the organic substrate layer. The vents were unevenly 
distributed across the bioreactor with most of them concentrated adjacent to the bioreactor cell outlet. Sediments accumulating on top of this uneven substrate underwent diagenetic transformations and developed contrasting hydrological properties, with high-permeability areas (HPA) associated with vent systems and low-permeability areas (LPA) associated with depressions.

\subsection{Sediment core sample collection}

Multiple sediment cores were collected in triplicate across the Tab Simco bioreactor at different sampling points using pre-cleaned plastic cylinders that were $7 \mathrm{~cm}$ in diameter and $\sim 120 \mathrm{~cm}$ in length. Before use, the cylinders were washed with diluted detergent, rinsed with diluted $\mathrm{NHO}_{3}$ followed by repeated rinses with DI water, and dried at room temperature for 24 h. We examined four sediment cores collected along a transect that stretched from one depression to the top of a proximate vent (Fig. 2a). Immediately after collection, the cores were divided in segments of $\sim 2 \mathrm{~cm}$ length and the individual subsamples were described, weighted, and dried at $50{ }^{\circ} \mathrm{C}$ for prompt geochemical and mineralogical analyses, respectively. For $\mathrm{pH}$ porewater measurements, immediately after the cores were sectioned, duplicate sediment segments were transferred to $50-\mathrm{mL}$ centrifuge tubes and centrifuged for $30 \mathrm{~min}$ at $8000 \mathrm{RCF}$ to separate pore waters from the sediments. The supernatant was collected and the $\mathrm{pH}$ and temperature measured using a Hanna ${ }^{\circledR}$ multi-sensor probe using the $\mathrm{pH}$ electrode Hanna HI769828-1 field probe (pH/ORP) which was calibrated with Orion $\mathrm{pH} 1.68,4.01$, and 7.00 buffers and checked against pH 10 buffer.

\subsection{Chemical characterization}

Quantitative determination of major elements was performed by total dissolution of sediment samples via strong multi-acid digestion and inductively coupled plasma mass spectrometry (ICP-MS) at the AcmeLabs Analytical Laboratories S.A. (Vancouver, Canada). A sample split of $0.25 \mathrm{~g}$ was heated in $\mathrm{HNO}_{3}-\mathrm{HClO}_{4}-\mathrm{HF}$ to fuming and then dried. The residue was dissolved in $\mathrm{HCl}$ and the supernatant analyzed by ICP-MS in low-, medium-, and high-resolution modes, depending on spectral interferences. A mixture of single-element standard solutions 
(OREAS24P and OREAS24E) was used for instrument calibration. The analytical precision $( \pm 1 \sigma$ ) of standard concentration values was $< \pm 0.05 \%$, whereas sample reproducibility was typically $<$ $\pm 0.1 \%$. The incomplete digestion of some detrital refractory materials, which we hypothesized might have been present in our samples, could had been only partial and thus the results of the ICM-MS analysis could have been affected. X-ray fluorescence is a physical method that does not suffer from difficulties such as small sample size, incomplete dissolution, matrix effects and sample inhomogeneity found in the acid digestion method. Therefore, duplicate splits were analyzed for (1) bulk concentrations of major oxides (i.e., $\mathrm{SiO}_{2}, \mathrm{Fe}_{2} \mathrm{O}_{3}, \mathrm{Al}_{2} \mathrm{O}_{3}$ ) by $\mathrm{LiBO}_{2}$ fusion followed by X-ray fluorescence (XRF) spectrometer analysis, and (2) total sulfur (TS) and total carbon (TC) contents were measured by Aqua Regia/ICP-MS analysis also at the AcmeLabs Analytical Laboratories S.A. The measurements were calibrated using the following certified reference materials SY-4(D), OREAS72B, GS311-1, and GS910-4. The analytical precision ( $\pm 1 \sigma$ ) of standard concentration values was $< \pm 0.1 \%$, whereas sample reproducibility was typically $<$ $\pm 0.2 \%$. The detection limit was $0.01 \%$ for $\mathrm{SiO}_{2}, \mathrm{Fe}_{2} \mathrm{O}_{3}, \mathrm{Al}_{2} \mathrm{O}_{3}$ and $0.02 \%$ for S. Minimal differences were observed between the ICP-MS and XRF chemical datasets suggesting that refractory minerals, if present, underwent complete dissolution during acid digestion. Therefore, in this study we report the chemical data obtained by acid digestion and inductively coupled plasma mass spectrometer (ICP-MS) analysis.

Total organic carbon (TOC) was determined in dried and acidified sediment samples using a LECO CR - 844 Carbon Analyzer also at the AcmeLabs Analytical Laboratories S.A. Powdered samples were treated with phosphoric acid (1:1) to remove inorganic carbon, dried at $105^{\circ} \mathrm{C}$, and then combusted in an oxygen-rich environment; any carbon present was converted to $\mathrm{CO}_{2}$ that was carried into a non-dispersive infrared (NDIR) detection cell where the mass of $\mathrm{CO}_{2}$ was measured by infrared spectrophotometer analysis. The mass was converted to percent total organic carbon based on the dry sample weight.

\subsection{Acid ammonium oxalate (AAO) extraction}

Duplicate dried AMD sediment samples were also subject to acid ammonium oxalate (AAO) extraction. During AAO extraction procedure, poorly-crystalline ferric and aluminum 
oxyhydroxysulfate phases, such as schwertmannite, hydrobasaluminite, and gibbsite, are dissolved by acid ammonium oxalate (Dold, 2003a, b; Gagliano et al., 2004; Caraballo et. al., 2009). In the case of complex Fe(III) mineral assemblages, only the poorly-crystalline goethite is dissolved during AAO, while well-crystallized goethite particles remain in solid form (Kumpulainen et al., 2007; Peretyazhko et al., 2009).

For the AAO extraction, a $50 \mathrm{mg}$ sediment sample was mixed with ammonium oxalate solution (28 g/L ammonium oxalate $\left(\left(\mathrm{NH}_{4}\right)_{2} \mathrm{C}_{2} \mathrm{O}_{4}\right)+15 \mathrm{~g} / \mathrm{L}$ oxalic acid $\left(\mathrm{H}_{2} \mathrm{C}_{2} \mathrm{O}_{4}\right)$ solution, $\mathrm{pH} \sim 2.7$; Peretyazhko et al., 2009). The mixtures were then shaken in the dark for 4 hours, then centrifuged (3000 rpm, $10 \mathrm{~min}$ ) and filtered $(<0.22 \mu \mathrm{m})$. The filtered supernatant solutions were analyzed by inductively coupled plasma mass spectrometer (ICP-MS), as previously described.

\subsection{Mineralogical characterization}

AMD sediments were characterized for their mineralogy using XRD, SEM, and FTIR analysis. XRD patterns were collected at Southern Illinois University in Carbondale (SIUC) using a Rigaku Ultima IV X-ray diffractometer with CuKa radiation. Diffractometer settings were: 40 $\mathrm{kV}, 30 \mathrm{~mA}$, and a scan range of $2-65^{\circ} 2 \theta, 0.05^{\circ} 2 \theta$ step size, and $20 \mathrm{~s}$ counting time per step. Bulk mineralogical data was collected on randomly oriented powders (e.g., Srodon et al. 2001; Moore and Reynolds, 1997). The identification of mineral phases was made both by utilizing the Jade 9.1, RockJock program and by comparing calculated d-spacing values with published crystal structure data. Selected samples were examined with a FEI Nova NanoSEM 430 field emission scanning electron microscope (SEM) fitted with backscattered and secondary electron detectors, coupled with an energy dispersive spectrometry (EDS) used for semi-quantitative compositional analyses at the IMAGE Facility, Southern Illinois University.

The FTIR spectroscopy in the middle infrared (MIR) region $\left(4000 \mathrm{~cm}^{-1}-400 \mathrm{~cm}^{-1}\right)$ was carried out at the University of Illinois at Urbana Champaign with a MIDAC M2000 FTIR spectrometer from MIDAC Corp. (Westfield, Massachusetts, USA) equipped with a DTGS detector. In the transmission mode the $\mathrm{KBr}$ pellets technique was used. The sample powders $(0.5 \mathrm{mg}$ ) were mixed and homogenized with $200 \mathrm{mg}$ of preheated (at 300 으 for $4 \mathrm{~h}$ ) $\mathrm{KBr}$ powder, and then pressed in the Evacuable Pellet Press for $13 \mathrm{~mm}$ pellets, PIKE Technologies up 
to $109,267 \mathrm{PSI}$. Prepared pellets were then heated overnight at $150^{\circ} \mathrm{C}$ to minimize water content in the samples and $\mathrm{KBr}$. The raw spectra were collected after 128 scans of resolution 2 $\mathrm{cm}^{-1}$ and processed using the OPERANT LLC Essential FTIR software package.

\subsection{Synchrotron X-ray Analysis}

Sediment samples were prepared at Spectrum Petrographic as standard $27 \times 46 \mathrm{~mm}$ Suprasil 2A quartz glass thin sections. Two samples were chosen, namely sample HPA-S3 as representative for a Fe-rich layer and LPA-S2 as representative for an Si-Al-rich layer. XRF elemental maps and Fe K XANES spectra were collected using the $\mathrm{x}$-ray microprobe at Beamline 13-ID-E (GSECARS) at the Advanced Photon Source (APS), Argonne, IL. A cryogenic, dual-crystal, $\mathrm{Si}(111)$ monochromator was used to feed monochromatic, undulator x-rays to a dual KB mirror system which focused the beam to $\sim 1 \mu \mathrm{m}$ (Sutton et al., 2002). XRF maps were obtained by scanning the sample in 2 micrometer steps in a grid over $500 \times 500$ micrometers and collecting the fluorescence (20 msec dwell time) using a quad Vortex Silicon Drift Detector (SDD). Fe K XANES spectra were obtained by collecting Fe Ka intensities (fluorescence mode, 1 sec dwell time) as the incident energy was scanned through the absorption edge (7030 to $7360 \mathrm{eV}$ ).

\subsection{Microbiological Analysis}

DNA was extracted at Southern Illinois University from soil core sections (stored at -20 ㅇ) using the PowerSoil ${ }^{\circledR}$ DNA Isolation Kit (MO BIO Laboratories, Inc.).16S rRNA Tag-Encoded FLX Amplicon Pyrosequencing (bTEFAP) was performed on the resulting purified DNA using the universal Eubacterial primers 27F (5'-AGAGTTTGATCMTGGCTCAG-3') and 530R (5'CCGCNGCNGCTGGCACS) by Molecular Research LP (Shallowater, Texas). Data derived from the Genome Sequencer FLX System (Roche) was processed using a proprietary analysis pipeline (www.mrdnalab.com) and barcode sequences, primers, and sequences of less than 200 bp were removed. Sequences with ambiguous base calls and sequences with homopolymer runs exceeding $6 \mathrm{bp}$ were also removed. The resulting data was then further analyzed using the Quantitative Insights into Microbial Ecology (QIIME) open source software package (v 1.9.0) (Caporoso, 2010). Using QIIME, an OTU (operational taxonomic unit) library containing 576627 
reads was constructed. Following quality filtering to remove chimeras, the remaining 445924 reads were clustered using the "Denoising Package" in QIIME and reads sharing 97\% sequence similarity or greater were assigned as the same OTU. This reduced the number of OTUs to 5183 , which were assigned class taxonomy using both BLAST and GreenGenes databases. Following the generation of class tables, OTUs representing $2 \%$ or less of the community were removed for graphical analysis. A heatmap was generated using the vegan, grid, RColorBrewer, ggplot2, gplots, heatmap.plus, colorRamps, and HeatPlus packages of the R Project for Statistical Computing.

\subsection{Statistical Interpretation}

The study of the statistical distribution of variables listed in Table SI-2 and the possible correlations among them (Table SI-2) was performed with STATGRAPHICS Centurion XVI.I - x64 statistical software.

\section{Results and discussion}

\subsection{Sediment chemistry and mineralogy}

The examination of in situ sediments in multiple cores revealed contrasting geochemical and mineralogical characteristics in HPA and LPA. The HPA sediments displayed relatively uniform major element concentrations, TOC, porewater $\mathrm{pH}$, and sediment water content (Fig. 3a; Table SI-1). In HPA-C1 core there were relatively small vertical variations of $\mathrm{Fe}_{\text {тот }}\left(\mathrm{Fe}_{\mathrm{avg}}=\right.$ $10,035 \mathrm{mM} / \mathrm{Kg} ; 1 \sigma= \pm 573 \mathrm{mM} / \mathrm{Kg})$, which was the primary component, $S_{\text {TOT }}$ below $5 \mathrm{~cm}\left(\mathrm{~S}_{\text {avg }}=\right.$ $847 \mathrm{mM} / \mathrm{Kg} ; 1 \sigma= \pm 176 \mathrm{mM} / \mathrm{Kg}), \mathrm{Si}_{\mathrm{TOT}}\left(\mathrm{Si}_{\mathrm{avg}}=426 \mathrm{mM} / \mathrm{Kg} ; 1 \sigma= \pm 259 \mathrm{mM} / \mathrm{Kg}\right)$, and $\mathrm{Al}_{\mathrm{TOT}}\left(\mathrm{Al}_{\mathrm{avg}}=\right.$ $181 \mathrm{mM} / \mathrm{Kg} ; 1 \sigma= \pm 109 \mathrm{mM} / \mathrm{Kg}$ ) concentrations (Table SI-1). We found an inverse correlation between the Fе тот and $\mathrm{Al}_{\text {тот }}$ concentrations, and no significant statistical relationship between $\mathrm{pH}$ and the major element concentrations (Table SI-2). This chemistry corresponded to a mineralogy dominated by goethite and schwertmannite, the latter identified mostly in the upper $(0-5 \mathrm{~cm}$ ) sediment layer (Fig. 3a). FTIR spectra of HPA-C1 sediment samples in the MIR region revealed a similar chemical composition of the entire sediment profile. In the region $3900 \mathrm{~cm}^{-1}-2700 \mathrm{~cm}^{-1}$ the stretching (v) vibrations of Fe-OH groups related to minerals goethite 
and schwertmannite were observed (Fig. 3a). Region $1800 \mathrm{~cm}^{-1}-1500 \mathrm{~cm}^{-1}$ provided the small band near $1650 \mathrm{~cm}^{-1}$ attributed to bending $(\delta)$ vibration of water molecules (Madejová and Komadel, 2001). The stretching S-O bands attributed to schwertmannite were found in 1300 $\mathrm{cm}^{-1}-950 \mathrm{~cm}^{-1}$ region, whereas the bending mode of S-O group was located near $610 \mathrm{~cm}^{-1}$ (Boily et al., 2010). The goethite presence was confirmed by a couple of bending $\mathrm{OH}$ vibrations $\delta(\mathrm{OH})$ and $\gamma(\mathrm{OH})$ at $892 \mathrm{~cm}^{-1}$ and $797 \mathrm{~cm}^{-1}$, respectively (Farmer, 1974).

Unlike HPA-C1, the sediments from LPA-C4 showed, unexpectedly, a downcore increase in the concentrations of $\mathrm{Si}_{\text {TOT }}$ (from 1900 to $10,080 \mathrm{mM} / \mathrm{Kg}$ ), $\mathrm{Al}_{\text {TOт }}$ (from 790 to $2800 \mathrm{mM} / \mathrm{Kg}$ ), and porewater $\mathrm{pH}$ (from 2.3 to 6.2) and a decrease in the concentrations of $\mathrm{Fe}_{\text {тот }}$ (from 8000 to $600 \mathrm{mM} / \mathrm{Kg}$ ), Sтот (from 650 to $35 \mathrm{mM} / \mathrm{Kg}$ ) and sediment water content (from 82 to 31\%) (Fig. 3b). For LPA-C4, significant correlations were found between $\mathrm{pH}$ values on one hand and $\mathrm{Fe}_{\text {TOт }}$ $(r=-0.94, p<0.0001), S_{\text {TOT }}(r=-0.88, p<0.0001), \mathrm{Al}_{\text {TOT }}(r=+0.95, p<0.0001)$, and $\mathrm{Si}_{\text {TOT }}(r=$ $+0.97, p<0.0001)$ on the other hand as well as among the major element concentrations (Table $\mathrm{SI}-2)$. The contrasting downcore gradients of Fe-S and Al-Si dominated chemistry corresponded to a striking mineralogical stratification, with an abrupt transition from a goethite-dominated mineralogy in the upper section to clay mineral- and quartz-dominated mineralogy in the lower section (Fig. 3b). This phenomenon was confirmed also by FTIR spectroscopy; increasing concentrations of $\mathrm{Al}$ and $\mathrm{Si}$ were identified by enlarging of stretching and bending vibrations of $\mathrm{Si}-\mathrm{O}$ and $\mathrm{OH}$ group related to kaolinite, illite, and quartz (Fig. 3b). Decreasing or absence of v(Fe$\mathrm{OH}), \delta(\mathrm{Fe}-\mathrm{OH}), v(\mathrm{~S}-\mathrm{O})$ and $\delta(\mathrm{S}-\mathrm{O})$ vibrations was caused by the lower Fe and $\mathrm{S}$ contents and the diminishing contribution of goethite to the FTIR spectra.

At the microscale, XRF elemental maps of AMD sediments provided more insight into the complex spatial distribution of selected chemical elements in samples representative of HPA and LPA (Fig. 4). Based on the expectation that the nNP components of these samples consist of Fe-rich phases (i.e., schwertmannite, goethite, lepidocrocite, and/or jarosite), Fe was used as an nNP proxy. XRF maps show contrasting spatial distribution of Fe in the two samples. In HPA-S3, Fe is present as alternating bands of high- and low-Fe, while in LPA-S2 Fe is present mostly as randomly-distributed, small-scale, high-Fe spots (Fig. 4). To evaluate the Fe speciation heterogeneity at a small scale, Fe K XANES spectra were collected in high and low Fe bands in 
HPA-S3 (spots 1 and 2, respectively) as well as in a high-Fe spot in LPA-S2 (Fig. 4). Comparison of Fe K XANES spectra (Fig. 5) shows that all three of these spectra are very similar and indicative of Fe with $3+$ valence. This data suggests that $\mathrm{Fe}^{2+}$-bearing phases, such as green rust, were not present in the AMD samples, and that goethite was probable the main $\mathrm{Fe}^{3+}$ mineral repository in both HPA and LPA sediments, result concurrent with the XRD and FTIR analyses.

The direct identification by synchrotron XRF analysis of clay minerals and quartz, which were the main dNP components in our samples, proved to be more challenging. Aluminum, which is the main proxy for clay minerals, was difficult to measure for two reasons: first, the low energy x-rays were highly absorbed in the sample and air path to the detector, and second, the possible strong interference from Si, which was abundant in our samples. Additionally, filtering the detector to reduce the Fe fluorescence intensity also prohibited us from seeing $\mathrm{Al}$ $x$-rays. On the other hand, the micro-XRD data provided chemical information sufficient to infer the distribution of detrital Si-Al-rich phases. Our approach was to measure $\mathrm{Zr}$ spectra as a proxy for the spatial distribution of detrital minerals and Ga spectra as a proxy for the spatial distribution of clay minerals.

Zirconium maps show dispersed high-Zr hot-spots in both LPA-S2 and HPA-S3. In the AMD sediments, $\mathrm{Zr}$ was likely incorporated as zircon $\left(\mathrm{ZrSiO}_{4}\right)$, which probably originated in the coal mine waste. Zircon is formed only under extreme temperatures and pressure and at Earth's surface is highly refractory and found as an accessory, detrital mineral ubiquitous in sedimentary rocks (Fedo et al., 2003). The size of the hot-spots in LPA-S2 is relatively larger than in HPA-S3, however in both cases the hot-spots are randomly-distributed within the sediment samples. The presence of these zircon grains supports the existence of a significant detrital component in the AMD sediments.

Because of the similar geochemical character with $\mathrm{Al}, \mathrm{Ga}$ is commonly found as a trace component in clays and other Si-Al-rich phases (Brantley et al., 1993; Brandt et al., 1998). In clays, $\mathrm{Ga}^{3+}$ is incorporated into nonexchangeable framework positions in the phyllosilicate sheets (Brandt et al., 1998) and as such in the present work Ga served as a proxy for clay-dNP. Ga XRF maps show distinct patterns in LPA-S2 and HPA-S3. In HPA-S3, similar to the pattern seen for the Fe XRF map, a layered structure is present where, although the Ga counts are low, 
there appears to be an inverse correlation between Fe and Ga where the lower Fe region (upper side) has higher Ga (and by inference Al) than the higher Fe region (lower side). In LPAS2 sample, Ga is rather uniformly distributed, suggesting ubiquitous presence of kaolinite. The hot spots seen in both Ga XRF maps are high Zr grains which produce high background in the Ga region of the XRF spectrum.

\subsection{AAO extraction of the AMD sediments}

The concentration values of AAO-extracted fractions showed contrasting trends for nNPassociated elements, namely $\mathrm{S}_{\mathrm{AAO}}$ and $\mathrm{Fe}_{\mathrm{AAO}}$, and dNP-associated elements, namely $\mathrm{Al}_{\mathrm{AAO}}$ and $\mathrm{Si}_{\mathrm{AAO}}$. Additionally, for all the elements considered, dissimilar depth profiles for AAO-extracted fractions were mapped in HPA-C1 and LPA-C4 (Fig. 6).

In all $A M D$ sediments, the amount of $A A O-e x t r a c t e d ~ s u l f u r ~\left(S_{A A O}\right)$ was practically identical to the amount of total $S\left(\mathrm{~S}_{\text {TOT }}\right)$ (Fig. $\left.6 \mathrm{a}, \mathrm{b}\right)$, with little or no $\mathrm{S}$ left in the sediments after AAO extraction. In HPA-C1, $\mathrm{S}_{\mathrm{AAO}}$ displayed the highest values of $1400 \mathrm{mM} / \mathrm{Kg}$ in the uppermost layer, decreasing downcore to $1000 \mathrm{mM} / \mathrm{Kg}$ at $\sim 5 \mathrm{~cm}$, and maintained relative constant downcore concentrations with an average $\mathrm{S}_{\mathrm{AAO}}$ value of $800 \mathrm{mM} / \mathrm{kg}$ (Fig. 6a). Conversely, in LPA-C4, $\mathrm{S}_{\mathrm{AAO}}$ decreased continuously downcore from $1200 \mathrm{mM} / \mathrm{Kg}$ at the top to $30 \mathrm{mM} / \mathrm{Kg}$ at $35 \mathrm{~cm}$, a concentration value that characterized the Si-Al-rich layer throughout the bioreactor (Fig. 6b). Since $\mathrm{SO}_{4}{ }^{2-}$ was the only $\mathrm{S}$ fraction in the AMD sediments and the concentrations of $\mathrm{S}_{\mathrm{AAO}}$ and $\mathrm{S}_{\text {TOт }}$ were analogous in both cores, we infer that $\mathrm{SO}_{4}{ }^{2-}$ was probably associated with either schwertmannite and/or poorly-crystalline goethite, both of which dissolved easily during AAO extractions (Peretyazhko et al., 2009).

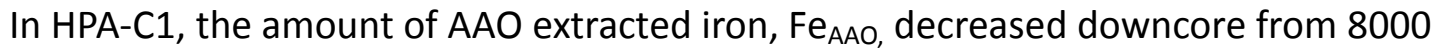
$\mathrm{mM} / \mathrm{kg}$ ( $\sim 90 \%$ of $\mathrm{Fe}_{\text {тот }}$ ) at the top to $2100 \mathrm{mM} / \mathrm{kg}$ ( $21 \%$ of $\mathrm{Fe}_{\text {тот }}$ ) at the bottom, in contrast to $\mathrm{Fe}_{\text {тот }}$ which exhibited relatively small vertical variations (Fig. 6a). This implies that even though the total amount of Fe-rich phases was relatively constant throughout the core, the ratio of well-crystallized to poorly-crystallized Fe-rich phases increased with depth during diagenesis as a result of dissolution-recrystallization processes (Manceau et al., 2000; Peretyazhko et al., 2009; Caraballo et al., 2013). Comparing the $\mathrm{S}_{\mathrm{AAO}}$ and $\mathrm{Fe}_{\mathrm{AAO}}$ downcore trends in HPA-C1, we 
infer that during transformation of amorphous and poorly-crystalline Fe-rich phases most of the $\mathrm{SO}_{4}{ }^{2-}$ was retained within the AMD sediments, most likely surface-complexed by goethite (Schwertmann and Carlson, 2005).

In LPA-C4, two contrasting downcore Fe $\mathrm{AAO}_{\mathrm{O}}$ trends were mapped (Fig. 6b). In the top 20 $\mathrm{cm}, \mathrm{Fe}_{\mathrm{AAO}}$ decreased with depth from $7100 \mathrm{mM} / \mathrm{Kg}$ ( $94 \%$ of $\mathrm{Fe}_{\mathrm{TOT}}$ ) at the top to $1700 \mathrm{mM} / \mathrm{Kg}$ ( $16 \%$ of $\mathrm{Fe}_{\text {тот }}$ ) at $20 \mathrm{~cm}$, while $\mathrm{Fe}_{\text {тот }}$ displayed relatively small variations around an average value of $8860 \mathrm{mM} / \mathrm{kg}$, an overall trend similar to that seen in HPA-C1. Dissimilarly, below a depth of $20 \mathrm{~cm}$, we observed a sudden, parallel drop in both $\mathrm{Fe}_{\text {TOT }}$ and $\mathrm{Fe}_{\mathrm{AAO}}$. The $\mathrm{Fe}$ concentration values decreased more than one order of magnitude from Fe and $\mathrm{Fe}_{\mathrm{AAO}}=1700 \mathrm{mM} / \mathrm{kg}$ at $20 \mathrm{~cm}$ to $\mathrm{Fe}_{\mathrm{TOT}} \leq 500 \mathrm{mM} / \mathrm{kg}$ and $\mathrm{Fe}_{\mathrm{AAO}} \leq 70 \mathrm{mM} / \mathrm{kg}$ at a depth of 50 $\mathrm{cm}$. These latter $\mathrm{Fe}_{\mathrm{TOT}}$ and $\mathrm{Fe}_{\mathrm{AAO}}$ values were mapped throughout the $\mathrm{Si}$-Al-rich layer of the bioreactor. Overall in LPA-C4, Fe AAO decreased markedly downcore from $7100 \mathrm{mM} / \mathrm{kg}$ ( 94\% of $\left.\mathrm{Fe}_{\text {тот }}\right)$ at the top to $70 \mathrm{mM} / \mathrm{kg}\left(\sim 12 \%\right.$ of $\mathrm{Fe}_{\text {тот }}$ ) at $50 \mathrm{~cm}$ suggesting that significant mineralogical changes occurred in LPA-C4 during the AMD sediment diagenesis.

In the upper layers $(0-20 \mathrm{~cm})$, similar to HPA-C1, the mineralogical changes included transformation of schwertmannite and poorly-crystallized goethite to well-crystallized goethite (Fig. 3a, b). For this upper layer, we infer that a higher amount of well-crystallized goethite was present in LPA-C4 since we recorded similar average Fe $_{\text {TOT }}$ and $\mathrm{S}_{\text {TOT }}$ values in LPA-C4 and HPA-C1 cores but extracted $39 \%$ less $\mathrm{Fe}_{\mathrm{AAO}}$ and $25 \%$ less $\mathrm{S}_{\mathrm{AAO}}$ in LPA-C4. In the lower layers $(20-50 \mathrm{~cm})$, the dramatic decrease in both $\mathrm{Fe}_{\mathrm{TO}}$ and $\mathrm{Fe}_{\mathrm{AAO}}$ indicate that most goethite, regarding of its crystallinity, was dissolved during AMD sediment diagenesis while little or no $\mathrm{Fe}$ and $\mathrm{SO}_{4}{ }^{2-}$ retained by the AMD sediments (Fig. 6b).

Conversely, the amount of oxalate extracted aluminum, $\mathrm{Al}_{\mathrm{AAO}}$, and silicon, $\mathrm{Si}_{\mathrm{AAO}}$, where relatively small with $4 \%$ of $\mathrm{Al}$ and $1 \%$ of Si were extractable in LPA-C4 sediments and $15 \%$ of $\mathrm{Al}$ and $11 \%$ of Si were extractable in HPA-C1 sediments (Fig. 6). The AAO extraction procedure has been shown to dissolve poorly-ordered Al oxide and sulfate precipitates, including Al-bearing minerals such as hydrobasaluminite and gibbsite (Caraballo et al., 20019). In case of our samples the XRD data provided no evidence for the presence of any crystalline or amorphous $\mathrm{Al}(\mathrm{OH})_{3}\left(\mathrm{Al}\right.$-hydroxide) phases, thus suggesting that the extracted $\mathrm{Al}_{\mathrm{AAO}}$ and $\mathrm{Si}_{\mathrm{AAO}}$ were probably 
the $\mathrm{Al}$ and Si fractions adsorbed and/or incorporated in the AAO-extractable Fe-rich phases (French et al., 2012; Sánchez-España et al., 2016). This hypothesis is also supported by the high molar ratios of $\mathrm{Fe}_{\mathrm{AAO}} / \mathrm{Al}_{\mathrm{AAO}}$ and $\mathrm{Fe}_{\mathrm{AAO}} / \mathrm{Si}_{\mathrm{AAO}}$ with values as high as 230 and 290 , respectively, and the SEM-EDS observations which showed the ubiquitous association of Al and Si with Fe-rich phases.

For HPA-C1, we found a significant correlation between $\mathrm{S}_{\mathrm{AAO}}$ on one hand and $\mathrm{Fe}_{\mathrm{AAO}}(\mathrm{r}=$ $0.75, \mathrm{p}<0.0001)$ and $\mathrm{Al}_{\mathrm{AAO}}(\mathrm{r}=0.74, \mathrm{p}<0.0001)$ on the other hand and no significant statistical relationship between $\mathrm{pH}$ and the main element concentrations (Table SI-2b). For LPA-C4, significant correlations were found between $\mathrm{pH}$ values on one hand and sediment water content (SWC\%) $(r=-0.94, p<0.0001), F_{A A O}(r=-0.76, p<0.0001), S_{A A O}(r=-0.88, p<0.0001)$, and $\mathrm{Si}_{\mathrm{AAO}}(\mathrm{r}=-0.94, \mathrm{p}>0.0001)$ on the other hand. Additionally, we found no significant statistical relationship between $\mathrm{pH}$ and $\mathrm{Al}_{\mathrm{AAO}}(r=-0.23, \mathrm{p}=0.27)($ Table SI-2b).

\subsection{Spatial distribution chemical parameters in AMD sediments}

At the field scale, examination of the spatial chemical variability through 2-D profiles extending from a depression to the nearby vent (Fig. 2a) revealed that extensive geochemical heterogeneities and a distinctive layered structure characterized the AMD sediments (Fig. 2b). The contrasting downcore geochemical and mineralogical gradients (Fig. 3, 6) correspond to a layered structure composed of an upper Fe-rich layer with an abrupt transition to a localized, lower Si-Al-rich layer (Fig. 7). These heterogeneities were the result of biogeochemical processes that occurred within the AMD sediments during the 6-year operation of TS bioreactor.

The Fe-rich sediment layer was characterized by low-pH porewater, elevated water contents, high concentrations of $\mathrm{Fe}_{\text {TOт }}$ and $\mathrm{S}_{\text {TOT, }}$, and low concentrations of $\mathrm{Al}_{\text {TOт }}$ and $\mathrm{Si}_{\text {TOт }}$ (Fig. 7; Table SI-1). The upper $(0-5 \mathrm{~cm})$ sediment layer displayed a homogenous composition throughout the bioreactor and had the highest values for $\mathrm{S}_{\text {тот }}$ and $\mathrm{Fe}_{\text {тот }}$ which can be linked to a mineralogy dominated by schwertmannite and amorphous and poorly-crystalline Fe-rich phases (Fig. 3). Transformation of these initially-precipitated phases occurred readily with the formation of goethite, the main Fe repository in the AMD sediments, which displayed increased 
crystallinity with depth throughout the Fe-rich layer. Commonly, $\mathrm{Fe}_{\text {TOт }}$ and $\mathrm{Al}_{\text {TOт }}$ showed local spatial variations which corresponded to layers with either high goethite/clay mineral ratios (higher Fe concentrations; dark-red color) or low goethite/clay mineral ratios (lower Fe concentrations; light-red color) (Fig. 2b; and HPA-S3 sample in Fig. 4).

Restricted AMD circulation in LPA allowed for more complex diagenetic transformation to occur within the AMD sediments, which included extensive dissolution of goethite and concentration of dNP in an Si-Al-rich layer (Fig. 3, 4, and 7). The Si-Al-rich sediment layer was characterized by high-pH porewater, relatively low sediment water contents, high concentrations of $\mathrm{Al}_{\text {TOт }}$ and $\mathrm{Si}_{\text {TOT, }}$, and negligible concentrations of $\mathrm{Fe}_{\text {TOт }}$ and $\mathrm{S}_{\text {TOт }}$ (Fig. 7; Table SI1). Mineralogically, the Si-Al-rich layer was dominated by the presence of clay minerals and quartz, with minor presence of other dNP (e.g., zircon) (Fig. 3 and 4). Kaolinite and illite were identified in the XRD and FTIR patterns of AMD samples from LPA-C4 lower section (Fig. 3b) with the overall clay abundance proportional to $\mathrm{Al}_{\text {TOT. }}$. Even though dNP were identified in all AMD sediments (Fig. 4; Section SI-2), LPA contained a higher dNP fraction than HPA (Fig. 3, 4), probably due to restricted AMD circulation in LPA and thus lower dissolution rates for dNP in these areas.

\subsection{Biogeochemical controls on precipitation and transformation of $n N P$.}

Previous research at TS has shown that dissolved Fe(II), resulted from the oxidative dissolution of pyrite in coalmine waste, was oxidized to ferric iron [Fe(III)] in the acid pond oxic waters either abiologically or by acidophilic iron oxidation microorganisms ( $\mathrm{FeO}$ ) of the class Betaproteobacteria and Alphaproteobacteria (Burns et al., 2012). The high molar ratio S:Fe of 4:1 in the acid pond assures ample supplies of $\mathrm{SO}_{4}{ }^{2-}$ for reaction and thus the produced $\mathrm{Fe}$ (III) was predominately complexed by $\mathrm{SO}_{4}{ }^{2-}$ and precipitated as schwertmannite, which was the main Fe phase detected by powder XRD and FTIR in the upper sediment layer (Fig. 3). The formation of these precipitates consumes substantial amounts of Fe and $\mathrm{SO}_{4}{ }^{2-}$ and releases protons.

Pyrosequencing of the microbial community present throughout the LPA column indicated that members of the Gammaproteobacteria, Alphaproteobacteria, Acidomicrobiia, 
and the uncharacterized JG37-AG-4 classes were the most abundant in the AMD sediments (Fig. 8). The top $30 \mathrm{~cm}$ of the LPA column, corresponding to the Fe-rich layer, was dominated by bacteria related to the Gammaproteobacteria class (60\%, $47 \%$, and $57 \%$ of the OTUs in the 10 , 20 , and $30 \mathrm{~cm}$ sections of the column, respectively) (Fig. 8). In the $30-50 \mathrm{~cm}$ intervals of the LPA column, corresponding to the Si-Al-rich layer, the abundance of Gamaproteobacteria phylotypes decreased significantly ( $12 \%$ and $4 \%$ of the detected OTUs, respectively) as abundance increases were detected for other classes. Because members of this bacterial class have been implicated in both acidic Fe oxidation and reduction (Shipeng et al., 2010; Johnson et al., 2012), we predict bacteria corresponding to these sequences are cycling Fe in the acidic sediments. Other noteworthy OTUs detected throughout the LPA column in various abundances were related to the Acidimicrobiia, Acidobacteriia, the uncharacterized JG37-AG-4, Alphaproteobacteria (most abundant below $30 \mathrm{~cm}$ with 22\% of the $50 \mathrm{~cm}$ OTUs), Nitrospira, and Clostridia classes (Fig. 8). Members of the first four classes have been implicated in iron cycling reactions in acidic environments (Coupland and Johnson, 2008; Bond et al., 2010; García-Moyano et al., 2012; Johnson et al., 2012). The Acidiphilium alphaproteobacteria is capable of reducing the Fe(III) in schwertmannite (Shipeng et al., 2010). In addition to oxidizing Fe(II), members of the Acidimicrobiia class are capable of reducing Fe(III) under oxygen limiting conditions (Bridge and Johnson, 1998). It should be noted that while a few genera within the Clostridia and Nitrospira classes have been shown to reduce sulfate (Kaksonen et al., 2004; Church et. al., 2007; SánchezAndrea, et. al., 2014), no corresponding OTUs were detected in the LPA column (data not shown).

In the AMD sediments, the opposing trends in the geochemical gradients for $\mathrm{Fe}_{\text {TOT }}-\mathrm{S}_{\text {TOT }}$ and $\mathrm{Al}_{\text {TOт }}-\mathrm{Si}_{\text {TOт }}$ (Fig. 3b) as well as in the abundances of microbial communities (Fig. 8) were probably the result of successive diagenetic processes. Schwertmannite, a poorly-crystalline $\mathrm{nNP}$, tends to aggregate and transform to goethite, which is a crystalline, more thermodynamically stable phase (Bigham and Nordstrom, 2000; Gagliano et al., 2004; Cornell and Schwertmann, 2003) with subsequent release of structural and adsorbed $\mathrm{SO}_{4}{ }^{2-}$ back into solution (Rose and Ghazi, 1997; Caraballo et al., 2013). Goethite, the primary Fe(III)-nNP repository in the AMD sediments (Fig. 3, 6), has low solubility in aqueous solutions (Lindsay, 
1979; Caraballo et al. 2013) and its overall thermodynamic stability is a function of crystal structure, composition and particle size. Mineralogical changes observed such as schwertmannite transformation to goethite and increased goethite crystallinity with depth may be explained by biologically-mediated Fe cycling processes in the AMD sediments. Significantly, the microbially-mediated mineralogical transformations in the Fe-rich layers seems to be dependent on the local hydrological conditions, with higher ratios of poorly crystalized goethite to well-crystallized goethite found in HPA.

Based on downcore decreasing $\mathrm{Fe}_{\mathrm{TOT}}$ and $\mathrm{Fe}_{\mathrm{AAO}}$ concentrations (Fig. 6), Fe minerals occurrence and distribution as revealed by XRD (Fig. 3), FTIR (Fig. 3), and XRF maps (Fig. 4), as well as the distribution of microbial communities (Fig. 8), we propose that extensive reductive dissolution of goethite took place (Fig. 6 a, b), up to total loss of crystalline Fe-rich phases in the lower section of LPA (Fig. 4; 6b). Various interconnected mechanisms including protonation, complexation, and reduction can contribute to the goethite dissolution. The significant inverse correlation between $\mathrm{Fe}_{\text {Tот }}$ content and porewater $\mathrm{pH}$ in the AMD sediments (Table SI-2) suggests that protonation had a minimum effect on goethite dissolution. Complexation by organic chelates and siderophores (Cheah et al., 2003; Kraemer et al., 2004), probably abundant in coal-generated AMD, could have increased the dissolution of goethite and the bioavailability of Fe(III) for microbial reduction in porewater. A combination of substitutions and structural defects in goethite crystals (Manceau et al., 2000) can also accelerate dissolution. Reduction of dissolved Fe(III) as well as amorphous and crystalline Fe(III)-nNP can occur both abiologically (e.g., via the redox cycling of humic acids; Lovley et al., 1996; Lovley et al., 1998) or biologically by the direct enzymatic reduction of Fe(III) oxides to Fe(II) by dissimilatory FeRB (DIRM, Lovley et al., 1991; Lovley, 1993). While in many environments goethite is less energetically suitable as electron acceptor for FeRB, in the AMD sediments, additional $\mathrm{H}_{2}$ and organic ligands from the underlying organic substrate layer could have provided inorganic electron donors for FeRB (Johnson and Hallberg, 2009). The net reactions for bacterial iron reduction, then, are strongly acid consuming and highly $\mathrm{pH}$-dependent. While current data cannot unequivocally determine the single important mechanisms, we suggest that a combination of abiotic and biological 
processes together with the development of favorable local conditions resulted in goethite dissolution.

\subsection{Role of clay-dNP in AMD contaminant dynamics}

Clay-dNP had a profound bearing on biogeochemical processes at the TS site due their unique properties, which include small size, large surface area, layer charge, and chemical reactivity towards both neutral and charged species as well as microorganisms.

Clay minerals, chiefly kaolinite and illite/smectite, are the main inorganic constituents in coals of Tradewater Formation (Murphysboro and Mt. Rorah coals) and overburden at the Tab Simco site (Fig. 9a), with $\mathrm{Al}_{2} \mathrm{O}_{3}$ content up to 20 weight \% measured in low-temperature ash (Lefticariu, 2009). The progressive weathering of coal and rapid dissolution of pyrite generates AMD enriched in dissolved $\mathrm{Fe}, \mathrm{SO}_{4}{ }^{2-}$, and heavy metals (Lefticariu, 2009) and leaves behind a residual composed of macerals, clay minerals, and quartz (Fig. 9b).

Under acidic $(<2.5)$ conditions, such as those in the Tab Simco coal mine waste (Segid, 2010), proton-promoted dissolution of clays results in decreased particle size and increased specific surface area, porosity and surface reactivity (Galan et al., 1999; Pentrak et al., 2012). Protons tend to adsorb on exchange sites and replace interlayer cations thus initiating a slow decomposition of the phyllosilicate layers by liberating octahedral cations (Komadel and Madejová, 2006). The extent of clay-acid interaction is controlled by crystal structure and chemical composition (Jozefaciuk and Bowanko, 2002) as well as solution chemistry. In mixed clays, preferential dissolution of smectite (Metz et al., 2005; Vazquez et al., 2011) is often observed over illite (Shaw and Hendry, 2009; Bibi et al., 2011) and kaolinite (Cama et al., 2002; Bibi et al., 2014), the latest being more resistant to acid attack due to restricted access of protons to the interlayer space and preferential dissolution limited to the particle edges.

At Tab Simco, we found that clay-dNP are relatively stable under low-pH conditions both in coal mine AMD and AMD sediments. Additional laboratory analyses of the AMD suspended load samples and AMD sediments treated by CDB (citrate-dithionite-bicarbonate extraction procedure) revealed the omnipresence of clay minerals at Tab Simco (Section SI-2). The acidmodified clay-dNP have unique properties (Komadel and Madejová, 2006), including high 
surface area/volume ratios as well as increased reactivity and catalytic properties, and thus provide a unique framework for interrelated microbial and geochemical processes.

Microorganisms, which are often present at or near clay surfaces as these are enriched in ions and organic matter relative to AMD (Kostka et al., 2002; Theng and Orchard, 1995), promoted complex biogeochemical reactions in AMD sediments. Concurrently, bacterial coatings and biofilm formation (Konhauser and Urrutia, 1999; Dong et al., 2009; Vasiliadou et al., 2011; Mueller, 2015), which has been observed in the presence of clay minerals (Maurice et al., 2001a), including smectite (Alimova et al., 2009; Perdrial et al., 2009), could have protected clay surfaces from sustained acid attack and created microniches for optimal microbial processes.

The clay-dNP provided reactive surfaces for heterogeneous nucleation and growth of nNP, especially Fe(III) phases (Fig. 9c) that have very small solubility products at low pH. At TS, this process was extensive since, as showed by XRD, FTIR, SEM data as well as in Fe XRF maps, dNP became totally encrusted within Fe(III)-nNP (Fig. 9 c-f). These Fe(III)-nNP coatings changed the surface reactivity and the point of zero charge (PZC) value of dNP and thus further modified the surface retention capacity for AMD pollutants. In the acid pond, increased particle size and variable charge surfaces of the growing nNP promoted flocculation, settlement, and ultimately the formation of the AMD sediment layer in the Tab Simco bioreactor cell.

In contrast, diagenetic processes in the AMD sediments catalyzed by clay-dNP promoted transformation and dissolution of nNP (Fig. 9 g, h). For example, the dissolution of goethite in the lower LPA (Fig. 6) could have resulted from a positive feedback process enhanced by claydNP: dissimilatory bacterial reduction of Fe(III) generated Fe(II) in porewater, which could have either diffused upwards or be adsorbed on goethite surfaces, which in turn accelerated the dissolution of goethite and thus produced more bioavailable Fe(III) for reduction. Partial dissolution of clay-dNP combined with FeRB processes generated porewater alkalinity, which changed local geochemical conditions and further favored FeRB activity (Komadel et al., 2006). This positive feedback was highly efficient only locally in the AMD sediments where AMD influx was restricted, such as in the lower LPA. Sustained AMD influx in the upper Fe-rich sediment layers and throughout HPA assured that any dissolution was balanced by fresh precipitation of Fe(III)-nNP (Fig. 6, 7). 
Diagenetic transformations also comprised decreasing sediment water content (Fig. 7) through mineral dehydration, transformation, and dissolution as well as sediment compaction. Dissolution of nNP favored the formation of a compact, low-permeability dNP layer (Fig. 4) capable of further decreasing AMD flow from the Tab Simco acid pond into the organic substrate layer. Over time, decreased AMD remediation in the bioreactor cell, as observed at Tab Simco, may have been related to the sealing properties of the clay-dNP layer.

\subsection{Calculation of the dNP influx at Tab Simco}

We estimate an average dNP influx to the Tab Simco bioreactor cell of $\sim 0.1 \mathrm{~g} / \mathrm{L}$ using an average AMD flow rate of $70 \mathrm{~L} / \mathrm{min}$ and a total AMD sediment volume of $1210 \mathrm{~m}^{3}$ and assuming that most dNP are concentrated in the Si-Al-rich layer (SI, Section S1). Sediment chemical analysis shows that for every mol of dNP influx, 2-14 mol of S and 7-44 mol of Fe were initially sequestered as nNP. Decreasing S/Fe molar ratios from 4/1 in the AMD influent, to 1/6 in the upper sediment layers, and further to $1 / 20$ in the lower sediment layer point to overall low $S$ sequestration in the AMD sediments. Our results also show that $S$, which in AMD sediments was predominantly associated with AAO fraction, could be easily remobilized during dissolution-recrystallization processes.

Iron sequestration as nNP in the AMD sediments, initially, was greatly efficient. However, long-term Fe sequestration was dependent on dissimilatory FeRB processes, which in turn where dependent on restricted access of AMD to the AMD sediments. Compared to HPA, increased reductive dissolution of goethite resulted in Fe mobilization with $\sim 50 \%$ Fe loss in upper LPA and up to $~ 95 \%$ Fe loss in lower LPA. During the six years of bioreactor operation, we estimate that $>90 \%$ of S and $>50 \%$ of Fe, initially sequestered as nNP were remobilized in solution during diagenesis of the AMD sediments through mineral transformation and dissolution. Work in progress at Tab Simco shows that the mechanisms of promoting sequestration and/or mobilization of the major AMD contaminants (e.g., Fe, S) were also a template for the behavior of trace metals, with major implications for long-term contaminant transport and immobilization in coal mining-impacted watersheds. 


\section{Conclusions and environmental implications}

Our study demonstrates for the first time that dNP inherited from the coal mine wastes can persist in low-pH mine drainages and become a support for biogeochemical processes that control the fate and transport of contaminants in watersheds affected by coal mining. At Tab Simco remediation site, the dNP fraction dominated by clay-minerals and quartz played a fundamental role in AMD contaminant dynamics. The presence of dNP highly enhanced AMD contaminant immobilization by providing support for nNP heterogeneous crystallization followed by precipitation. It is proposed that the AMD sediment started accumulating as quartz- and clay-dNP coated with schwertmannite and poorly-crystalline goethite. Sulfate, the chief dissolved component in coal mine AMD, was initially sequestered either as $\mathrm{SO}_{4}$-rich nNP (e.g., schwertmannite) and/or surface-bound to poorly-crystalline goethite. Depending on local hydrological conditions, subsequent transformations of nNP resulted in partial or total $\mathrm{SO}_{4}$ remobilization. This result is significant since it shows that $\mathrm{SO}_{4}{ }^{2-}$, which in AMD sediments at Tab Simco was exclusively associated with AAO extractable fraction, can be easily remobilized during subsequent microbially-mediated processes. Iron, which is also a major dissolved contaminant in coal mine AMD, was predominantly sequestered in AMD sediments as Fe(III)rich nNP (e.g., goethite). However, similar to S, the Fe(III)-rich nNP were subsequently prone to dissolution/recrystallization processes. When the biogeochemical conditions within the AMD sediments started favoring iron reduction, the well-crystallized goethite nNP coatings were dissolved that resulted in partial or total Fe remobilization which left behind a dNP-rich layer dominated by clay-minerals and quartz. Overall, recrystallization and dissolution of nNP greatly contributed to remobilization of coal mine AMD contaminants.

In watersheds affected by coal mining activities both dNP and nNP can contribute in complex and subtle ways not only to local contaminant immobilization but also to long-run contaminant transport since coated dNP may be less affected by dissolution and thus prone to long-distance contaminant transport and dispersion. Promoting the precipitation of Fe(III)-rich nNP in natural and/or engineered system (e.g., engineered wetlands, terraced iron formations), can only be a short-term approach to AMD remediation, since subsequent transformations of the AMD sediments may result in contaminant remobilization. Excessive accumulation of 
precipitates as unwanted scale and/or layers within different components of a natural watershed and/or AMD remediation system, such was the case of Tab Simco sulfate-reducing bioreactor, can further impede the normal functions of these natural and/or engineered systems. Furthermore, nNP can incorporate toxic elements (e.g., $\mathrm{Cd}, \mathrm{Cr}, \mathrm{Ni}, \mathrm{Pb}$, and $\mathrm{Zn}$ ) either structurally or adsorbed, so the solubility of nNP may govern the sequestration and transport of contaminants in coal mining impacted sites.

Highlighting the key role that dNP play in contaminant transport and sequestration, could lead not only to better understanding of mechanisms that govern the transport, immobilization and removal of contaminants in watersheds affected by historical and active coal mining activities but also to novel, better technologies for treatment of contaminated drainage associated with coal mining and beyond. Finally, other areas of coal and coal waste utilization, such as the design of bio/geo-engineering technologies for metal recovery from mining waste, may benefit from our findings.

\section{Acknowledgements}

Funding for this study was provided by the Office of Surface Mining Reclamation and Enforcement (OSM) Applied Science Program Cooperative Agreement S11AC20018 AS. Portions of this work were performed at GeoSoilEnviroCARS (Sector 13), Advanced Photon Source (APS), Argonne National Laboratory. GeoSoilEnviroCARS is supported by the National Science Foundation - Earth Sciences (EAR-1128799) and Department of Energy- Geosciences (DE-FG0294ER14466). This research used resources of the Advanced Photon Source, a U.S. Department of Energy (DOE) Office of Science User Facility operated for the DOE Office of Science by Argonne National Laboratory under Contract No. DE-AC02-06CH11357. 


\section{REFERENCES}

Alimova, A., Katz, A., Steiner, N., Rudolph, E., Wei, H., Steiner, J.C., Gottlieb, P., 2009. Bacteriaclay interaction: structural changes in smectite induced during biofilm formation. Clays Clay Miner. 57, 205-212.

Baker, B.J., Banfield, J.F., 2003. Microbial communities in acid mine drainage. FEMS Microb. Ecol. 44(2), 139-152.

Brantner, J.S., Haake, Z.J., Burwick, J.E., Menge, C.M., Hotchkiss, S.T., Senko, J.M., 2014. Depthdependent geochemical and microbiological gradients in Fe (III) deposits resulting from coal mine-derived acid mine drainage. Frontiers in microbiology, 5.

Behum, P.T., Lefticariu, L., Bender, K.S., Segid, Y. T., Burns, A. S., Pugh, C.W., 2011. Remediation of coal-mine drainage by a sulfate-reducing bioreactor: A case study from the Illinois coal basin, USA. Appl. Geochem. 26, S162-S166.

Bibi, I., Singh, B., Silvester, E. 2011. Dissolution of illite in saline-acidic solutions at $25^{\circ} \mathrm{C}$. Geochim. Cosmochim. Acta 75, 323-3249.

Bibi, I., Singh, B., Silvester, E. 2014. Dissolution kinetics of soil clays in sulfuric acid solutions: Ionic strength and temperature effects. Appl. Geochem. 51, 170-183.

Bigham, J.M., Schwertmann, U. Traina, S.J., Winland, R.L., Wolf, M. 1996. Schwertmannite and the chemical modeling of iron in acid sulfate waters. Geochim Cosmochim Acta 60, 2111-2121.

Bigham, J.M., Nordstrom, D.K. 2000. Iron and aluminum hydroxysulfates from acid sulfate waters. Rev. Mineral. Geochem. 40, 351-403.

Blowes, D.W., Ptacek, C. J., Jambor, J.L., Weisener, C.G., Paktunc, D., Gould, W.D., Johnson, D. B., 2014.The geochemistry of acid mine drainage. In: Sherwood Lollar, B. (Ed.), Environmental Geochemistry. Holland, H.D., Turekian, K.K. (Exec. Eds.), Treatise on Geochemistry, vol. 11. Elsevier, pp. 113-190.

Boily, J.-F., Gassman, P.L., Peretyazhko, T., Szanyi, J., Zachara, J. M., 2010. FTIR spectral components of schwertmannite. Environ. Sci. Technol. 44, 1185-1190.

Bond, P.L., Smriga, S.P., Banfield, J.F., 2000. Phylogeny of microorganisms populating a thick, subaerial, predominantly lithotrophic biofilm at an extreme acid mine drainage site. Appl. Environ Microbiol. 66, 3842-3949.

Borch, T., Kretzschmar, R., Kappler, A., Cappellen, P.V., Ginder-Vogel, M., Voegelin, A., Campbell, K., 2009. Biogeochemical redox processes and their impact on contaminant dynamics. Environ. Sci. Technol. 44, 15-23. 
Bradley, S. M.; Howe, R. F.; Kydd, R. A., 1993.Correlation between ${ }^{27} \mathrm{Al}$ and ${ }^{71} \mathrm{Ga} N \mathrm{NM}$ chemical shifts. Magn. Reson. Chem. 31, 883-886.

Brandt, K.B., Kydd, R.A., 1998. Gallium and chromium substitution for aluminum in synthesized beidellite. Clays Clay Minera. 46, 139-144.

Braunschweig, J., Bosch, J., Meckenstock, R.U., 2013. Iron oxide nanoparticles in geomicrobiology: from biogeochemistry to bioremediation. N. Biotechnol. 30, 793-802.

Bridge, T. A. M., Johnson, D.B., 1998. Reduction of soluble iron and reductive dissolution of ferric iron-containing minerals by moderately thermophilic iron-oxidizing bacteria. Appl. Environ. Microbiol. 64(6), 2181-2186.

Burgos, W.D., Borch, T., Troyer, L., Luan, F., Larson, L., Brown, J.F., Shimizu, M., 2012. Schwertmannite and Fe oxides formed by biological low-pH Fe (II) oxidation versus abiotic neutralization: Impact on trace metal sequestration. Geochim. Cosmochim. Acta 76, 29-44.

Burns, A.S., Pugh, C.W., Segid, Y.T., Behum, P.T., Lefticariu, L., Bender, K.S. 2012. Performance and microbial community dynamics of a sulfate-reducing bioreactor treating coal generated acid mine drainage. Biodegradation 23, 415-429.

Cama, J., Metz, V., Ganor, J., 2002. The effect of pH and temperature on kaolinite dissolution rate under acidic conditions. Geochim. Cosmochim. Acta 66, 3913-3926.

Caporaso J.G., Kuczynski, J., Stombaugh, J., Bittinger, K., et. al. 2010. QIIME allows analysis of high-throughput community sequencing data. Nature Meth. 7, 335-336.

Caraballo, M.A., Rotting, T.S., Nieto, J.M., Ayora, C., 2009. Sequential extraction and DXRD applicability to poorly crystalline Fe- and Al-phase characterization from an acid mine water passive remediation system. Amer. Mineral. 94, 1029-1038.

Caraballo, M.A., Rimstidt, J.D., Macías, F., Nieto, J.M., Hochella, M.F., 2013. Metastability, nanocrystallinity and pseudo-solid solution constraints to schwertmannite solubility. Chem. Geol. 360/361, 22-31.

Cheah, S.F., Kraemer, S.M., Cervini-Silva, J., Sposito, G. 2003. Steady-state dissolution kinetics of goethite in the presence of desferrioxamine $B$ and oxalate ligands: implications for the microbial acquisition of iron. Chem. Geol. 198, 63-75.

Church, C.D., Wilkin R.T., Alpers, C.N., Rye, R.O., McCleskey, R.B., 2007. Microbial sulfate reduction and metal attenuation in pH 4 acid mine water. Geochem. Trans. 8:10, 1-14. 
Comolli, L.R., Banfield, J.F., 2014. Inter-species interconnections in acid mine drainage microbial communities. Front. Microbiol. 5, 367.

Cornell, R.M., Schwertmann, U. 2003. The Iron Oxides: Structure, Properties, Reactions, Occurrence and Uses; $2^{\text {nd }}$ ed.; Wiley VCH Publishers: New York, pp. 703.

Coupland, K., Johnson, D.B., 2008. Evidence that the potential for dissimilatory ferric iron reduction is widespread among acidophilic heterotrophic bacteria. FEMS Micro Lett. 279, 30-35.

Cravotta, C.A., III., 2008. Dissolved metals and associated constituents in abandoned coal-mine discharges, Pennsylvania, USA. 1. Constituent concentrations and correlations. Appl. Geochem. 23, 166-202.

DiLoreto, Z.A., Weber, P.A., Weisener, C.G., 2016. Solid phase characterization and metal deportment in a mussel shell bioreactor for the treatment of AMD, Stockton Coal Mine, New Zealand. Appl. Geochem. 67, 133-143.

Dold, B., 2003a. Dissolution kinetics of schwertmannite and ferrihydrite in oxidized mine samples and their detection by differential X-ray diffraction (DXRD). Appl. Geochem. 18, 15311540.

Dold, B., 2003b. Speciation of the most soluble phases in a sequential extraction procedure adapted for geochemical studies of copper sulfide mine waste. J. Geochem. Explor. 80, 55-68.

Dong, H., Jaisi, D.P., Kim, J. and Zhang, G., 2009. Review Paper. Microbe-clay mineral interactions. Am. Mineral. 94, 1505-1519.

Farmer, V.C., 1974. The infrared spectra of minerals. Monograph 4. Mineralogical Society, London, $539 \mathrm{pp}$.

French, R.A., Caraballo, M.A., Kim, B., Rimstidt, J.D., Murayama, M., Hochella, M.F., 2012. The enigmatic iron oxyhydroxysulfate nanomineral schwertmannite: Morphology, structure, and composition. Am. Mineral. 97, 1469-1482.

Fedo, C.M., Sircombe, K.N., Rainbird, R.H., 2003. Detrital zircon analysis of the sedimentary record. Rev. Mineral. Geochem. 53(1), 277-303.

Gagliano, W.B., Brill, M.R., Bigham, J.M., Jones, F.S., Traina, S.J., 2004. Chemistry and mineralogy of ochreous sediments in a constructed mine drainage wetland. Geochim. Cosmochim. Acta 68, 2119-2128.

Galan, E., Carretero M.I., Fernandez-Caliani, J.C., 1999. Effects of acid mine drainage on clay minerals suspended in the Tinto River (Rio Tinto, Spain). An experimental approach. Clay Miner. 34, 99-112. 
García-Moyano, A., González-Toril, E., Aguilera, A., Amils, R., 2012. Comparative microbial ecology study of the sediments and the water column of the Río Tinto, an extreme acidic environment. FEMS Micro- biol. 81, 303-314.

Hansel, C.M., Benner, S.G., Neiss, J., Dohnalkova, A., Kukkadapu, R.K., Fendorf, S., 2003. Secondary mineralization pathways induced by dissimilatory iron reduction of ferrihydrite under advective flow. Geochim. Cosmochim. Acta 67, 2977-2992.

Hochella, M.F., Lower, S.K., Maurice, P.A., Penn, R L., Sahai, N., Sparks, D.L., 2008. Twining, B. S. Nanominerals, mineral nanoparticles, and earth systems. Science 319, 1631-1635.

Hochella, M. F., Moore, J.N., Putnis, C., Putnis, A., Kasama, T., Eberl, D.D., 2005. Direct observation of heavy metal-mineral association from the Clark Fork River Superfund Complex: Implications for metal transport and bioavailability. Geochim. Cosmochim. Acta 69, 1651-1663.

Hudson-Edwards, K.A., 2003. Sources, mineralogy, chemistry and fate of heavy metal-bearing particles in mining-affected river systems. Mineral. Mag. 67, 205-217.

Hudson-Edwards, K., 2016. Tackling mine wastes. Science 352(6283), 288-290.

Johnson, D. B., Hallberg, K.B., 2008. Carbon, iron and sulfur metabolism in acidophilic microorganisms. Adv. Microb. Physiol. 54, 201-255.

Johnson, D.B., Kanao, T., Hedrich, S. 2012. Redox transformations of iron at extremely low pH: fundamental and applied aspects. Front Microbio. 3, 96.

Jozefaciuk, G., Bowanko, G., 2002. Effect of acid and alkali treatments on surface areas and adsorption energies of selected minerals. Clays Clay Miner. 50(6), 771-783.

Kaksonen, A.H., Plumb, J.J., Franzmann, P.D., Puhakka, J.A., 2004. Simple organic electron donors support diverse sulfate-reducing communities in fluidized-bed reactors treating acidic metal- and sulfate-containing wastewater. FEMS Microbiol. Ecol. 47, 279-289.

Komadel, P., Madejová, J., 2006. Acid activation of clay minerals. In: Handbook of Clay Science, Bergaya, F., Theng, B. K. G., Lagaly, G., Eds., Elsevier: Amsterdam pp.263-287.

Komadel, P., Madejova, J., Stucki, J.W., 2006. Structural Fe(III) reduction in smectites. Applied Clay Sci. 34, 88-94.

Konhauser, K.O., Urrutia, M.M., 1999. Bacterial clay authigenesis: a common biogeochemical process. Chem. Geol. 161(4), 399-413. 
Kostka, J. E., Dalton, D.D., Skelton, H., Dollhopf, S., Stucki, J.W., 2002. Growth of iron (III)reducing bacteria on clay minerals as the sole electron acceptor and comparison of growth yields on a variety of oxidized iron forms. Appl. Environ. Micro. 8, 6256-6262.

Kraemer, S.M. 2004. Iron oxide dissolution and solubility in the presence of siderophores. Aquat. Sci. 66, 3-18.

Kumpulainen, S., Carlson, L., Raisanen, M.L., 2007. Seasonal variations of ochreous precipitates in mine effluents in Finland. Appl. Geochem., 22 (4), 760-777.

Küsel, K., Roth,U., Drake, H., 2002. Microbial reduction of Fe(III) in the presence of oxygen under low pH conditions. Environ. Microbiol. 4, 414-421.

Küsel, K., 2003. Microbial cycling of iron and sulfur in acidic coal mining lake sediments. Water Air Soil Pollut. 3, 67-90.

Küsel, K., Blöthe, M., Schulz, D., Reiche, M., Drake, H.L., 2008. Microbial reduction of iron and porewater biogeochemistry in acidic peatlands. Biogeosciences Discussions 5(3), 2165-2196.

Lagaly, G., 2006. Colloid clay science. In: Handbook of Clay Science, Bergaya, F., Theng, B. K. G., Lagaly, G., Eds., Elsevier: Amsterdam, pp. 141-245.

Lefticariu, L., 2009. Integrated study of mercury and other trace elements distribution in Illinois Coal. Final report to Illinois Clean Coal Institute, 44 pp.

Lefticariu, L., Walters, E.R., Pugh, C.W., Bender, K.S., 2015. Sulfate reducing bioreactor dependence on organic substrates for remediation of coal-generated acid mine drainage: Field experiments. Appl. Geochem., 63, 70-82.

Lovley D.R., 1991. Dissimilatory Fe(III) and Mn(IV) reduction. Microb. Rev. 55, 259-287.

Lovley, D.R., Giovannoni, S.J., White, D.C., Champine, J.E., Phillips, E., Gorby, Y.A., Goodwin, S., 1993. Geobacter metallireducens gen. nov. sp. nov., a microorganism capable of coupling the complete oxidation of organic compounds to the reduction of iron and other metals. Arch. Micro. 159, 336-344.

Lovley, D.R., Coates, J.D., Blunt-Harris, E.L., Phillips, E.J., Woodward, J.C., 1996. Humic substances as electron acceptors for microbial respiration. Nature 382, 445-448.

Lu, S., Gischkat, S., Reiche, M., Akob, D.M., Hallberg, K.B., Küsel, K., 2010. Ecophysiology of Fecycling bacteria in acidic sediments. Appl. Environ. Microbiol. 76, 8174-8183. 
Lu, S., Chourey, K., Reiche, M., Nietzsche, S., Shah, M.B., Neu, T.R., Hettich, R.L. Küsel, K., 2013. Insights into the structure and metabolic function of microbes that shape pelagic iron-rich aggregates ("iron snow"). Appl. Environ. Microbiol. 79(14), 4272-4281.

Luther III, G.W., Rickard, D.T., 2005. Metal sulfide cluster complexes and their biogeochemical importance in the environment. J. Nanoparticle Res. 7, 389-407.

Madejová, J., Komadel, P., 2001. Baseline studies of the Clay Mineral Society Source Clays: Infrared Methods. Clay. Clay. Miner. 49, 410-432.

Manceau, A., Schlegel, M.L., Musso, M., Sole, V.A., Gauthier, C., Petit, P.E., Trolard, F., 2000. Crystal chemistry of trace elements in natural and synthetic goethite. Geochim. Cosmochim. Acta 64, 3643-3661.

Maurice, P.A., Vierkorn, M.A., Hersman, L.E., Fulghum, J.E., 2001. Dissolution of well and poorly ordered kaolinites by an aerobic bacterium. Chem Geol 180, 81-97.

Metz, V., Amram, K., Ganor, J., 2005. Stoichiometry of smectite dissolution reaction. Geochim. Cosmochim. Acta 69, 1755-1767.

Mueller, B., 2015. Experimental interactions between clay minerals and bacteria: a review. Pedosphere 25(6), 799-810.

Moore, D.M., Reynolds, R.C., Jr., 1997. X-ray diffraction and the identification and analysis of clay minerals. Oxford University Press: New York. 378 p.

Navrotsky, A., Mazeina, L., Majzlan, J., 2008. Size-driven structural and thermodynamic complexity in iron oxides. Science 319(5870), 1635-1638.

Nordstrom, D.K., Blowes, D.W. and Ptacek, C.J., 2015. Hydrogeochemistry and microbiology of mine drainage: An update. Appl. Geochem. 57, 3-16.

Pentrak, M., Czímerová, A., Madejová, J., Komadel, P., 2012. Changes in layer charge of clay minerals upon acid treatment as obtained from their interactions with methylene blue. Appl. Clay Sci. 55, 100-107.

Peretyazhko, T., Zachara, J.M., Boily, J.F., Xia, Y., Gassman, P L., Arey, B.W., Burgos, W.D., 2009. Mineralogical transformations controlling acid mine drainage chemistry. Chem. Geol. 262, 169178.

Perdrial, J.N., Warr, L.N., Perdrial, N., Lett, M.C., Elsass, F., 2009. Interaction between smectite and bacteria: implications for bentonite as backfill material in the disposal of nuclear waste. Chem Geol 264, 281-294. 
Roden, E.E., 2012. Microbial iron-redox cycling in subsurface environments. Biochem. Soc. Trans. 40, 1249-56.

Rose, S., Ghazi, A.M., 1997. Release of sorbed sulfate from iron oxyhydroxides precipitated from acid mine drainage associated with coal mining. Environ. Sci. Technol. 31, 2136-2140.

Sánchez-Andrea, I., Rodriguez, N., Amils, R., Sanz, J.L., 2011. Microbial diversity in anaerobic sediments at Rio Tinto, a naturally acidic environment with a high heavy metal content. Appl. Environ. Microbiol. 77, 6058-6093.

Sánchez-Andrea, Sanz, J.L., Bijmans, M.F.M., Stams, A.J.M., 2014. Sulfate reduction at low pH to remediate acid mine drainage. J. Hazard. Mater. 269, 98-109.

Sánchez-España, J., Yusta, I., Gray, J., Burgos, W.D., 2016. Geochemistry of dissolved aluminum at low pH: Extent and significance of Al-Fe (III) coprecipitation below pH 4.0. Geochim. Cosmochim. Acta 175, 128-149.

Segid, Y.T., 2010. Evaluation of the Tab-Simco acid mine drainage treatment system: water chemistry, performance, and treatment processes. Unpubl. M.S. thesis. Southern Illinois Univ., Carbondale.

Shaw, S.A., Peak, D., Hendry, M.J., 2009. Investigation of acidic dissolution of mixed clays between $\mathrm{pH} 1.0$ and- 3.0 using Si and Al X-ray absorption near edge structure. Geochim. Cosmochim. Acta 73, 4151-4165.

Shipeng L., Gischkat, S., Reiche, M., Akob, D.M., Hallberg, K.B., Küsel, K., 2010. Ecophysiology of Fe-cycling bacteria in acidic sediments. Appl. Environ. Microbiol. 76, 8174-8183.

Srodon, J., Drits, V.A., McCarty, D K., Hsieh, J.C., Eberl, D.D., 2001. Quantitative X-ray diffraction analysis of clay-bearing rocks from random preparations. Clays Clay Minera. 49, 514-528.

Sutton S.R., Bertsch P.M., Newville M., Rivers M., Lanzirotti A., Eng P., 2002. Microfluorescence and microtomography analyses of heterogeneous earth and environmental materials. Rev. Mineral. Geochem. 49(1), 429-483.

Theng, B.K.G., Orchard, V.A., 1995. Interactions of clays with microorganisms and bacterial survival in soil: A physicochemical perspective. In: Environmental Impact of Soil Component Interactions; Huang, P. M., Berthelin, J., Bollag, J.M., McGill, W. B., Page, A.L. Eds.; CRC Press, Florida pp. 123 -139.

Vazquez, O., Monnell, J.D., Pu, X., Neufeld, R.D., 2011. Major processes dominating the release of aluminum from smectite clays when leached with acid mine drainage. Environ. Eng. Sci. 28, 163-169. 
Vasiliadou, I.A., Papoulis, D., Chrysikopoulos, C.V., Panagiotaras, D., Karakosta, E., Fardis, M. and Papavassiliou, G., 2011. Attachment of Pseudomonas putida onto differently structured kaolinite minerals: a combined ATR-FTIR and $1 \mathrm{H}$ NMR study. Colloids and Surfaces B:

Biointerfaces, 84(2), pp.354-359.

Waychunas, G.A., Kim, C.S., Banfield, J F., 2005. Nanoparticulate iron oxide minerals in soils and sediments: unique properties and contaminant scavenging mechanisms. J. Nanopart. Res. 7, 409-433.

Yang, Y., Colman, B.P., Bernhardt, E.S., Hochella, M.F., 2015. Importance of a nanoscience approach in the understanding of major aqueous contamination scenarios: case study from a recent coal ash spill. Environ. Sci. Technol. 49, 3375-3382.

Zachara, J.M., Kukkadapu, R.K., Fredrickson, J.K., Gorby, Y.A., Smith, S.C., 2002. Biomineralization of poorly crystalline Fe (III) oxides by dissimilatory metal reducing bacteria (DMRB). Geomicrob. J. 19(2), pp.179-207.

\section{FIGURE CAPTIONS}

Figure 1: (a) Overview looking north of the Tab-Simco sulfate-reducing bioreactor treatment system. (b) Cross section view of the Tab-Simco sulfate-reducing bioreactor.

Figure 2: Overview of the sediment layer accumulated at the Tab Simco passive treatment system within the bioreactor cell over a 6-year period when the TS actively remediated the coalmine AMD. The sediments accumulated on top of the organic substrate matrix underwent diagenetic transformations and developed contrasting hydrological properties, with highpermeability areas (HPA) associated with vent systems and low-permeability areas (LPA) associated with depressions. (b) Close-up view of a LPA where sediments have a striking mineralogical stratification, with an abrupt transition from a goethite-dominated mineralogy in the upper section to a clay minerals-dominated mineralogy in the lower section. (c) Close-up view of a HPA, where the vent system provided greater hydrological connectivity between the acid pond and the underlying organic substrate layer and increased preferential transport of not only gasses out of the OM but also of AMD from the AP into the OM. (d) Close-up view of a HPA, which was characterized by monotonous mineralogy dominated by goethite.

Figure 3: Geochemical and mineralogical depth profiles in two cores collected from a AMD sediment layer accumulated on top of the Tab Simco bioreactor cell over a 6-year period. (a) Core HPA-C1 was collected from a high-permeability area (HPA) and (b) core LPA-C4 was collected from a low-permeability area (LPA). Details are described in Section S1 of the Supporting Information. Chemical data presented includes porewater $\mathrm{pH}$, sediment TOC, and the total $\mathrm{Fe}, \mathrm{S}, \mathrm{Al}$, and $\mathrm{Si}$ concentrations in AMD sediments. Mineralogical data include XRD and FIRT patterns of untreated AMD sediments. 
Figure 4: Images of the LPA-S2 (right) and HPA-S3 (left) samples. Top image are visible light microscope images of the areas chosen for elemental mapping with the XRM. Below those are the XRF maps for $\mathrm{Fe}, \mathrm{Zr}$, and $\mathrm{Ga}$. The three labeled locations on the Fe maps are positions where Fe K XANES spectra were collected (see Figure 3). All images are 500 × 500 micrometers.

Figure 5: Fe K XANES spectra for LPA-S2 and two spots (high Fe, low Fe) on the HPA-S3 sample (see analysis locations in Fe maps of Figure 2). The inset shows the $\mathrm{Fe}^{3+}$ dominated pre-edge peak structure.

Figure 6: Geochemical depth profiles of the concentrations for $\mathrm{Fe}, \mathrm{S}, \mathrm{Al}$, and $\mathrm{Si}$ in AMD sediments (TOT) and the solid fraction left after the acid ammonium oxalate extraction (TOTAAO) in two cores collected from the AMD sediment layer accumulated on top of the Tab Simco bioreactor cell over a 6-year period. (a) Core HPA-C1 was collected from a high-permeability area (HPA) and (b) core LPA-C4 was collected from a low-permeability area (LPA).

Figure 7: Contour plots of porewater $\mathrm{pH}$, sediment water content (SWC \%), and elemental concentration for $\mathrm{Fe}, \mathrm{S}, \mathrm{Al}$, and $\mathrm{Si}$ in AMD sediments along a 2-D profile [depth from the sediment top $(\mathrm{cm})$ vs. distance between a HPA to the nearby LPA $(\mathrm{cm})]$.

Figure 8: Heatmap displaying the relative bacterial class abundances of specific OTUs within the LPA core. Only OTUs representing $>2 \%$ of the total are presented. Density percentages are represented by the color key.

Figure 9: SEM images of solid components of the Tab-Simco remediation system. (a) Unweathered Murphysboro coal sample containing bands of organic macerals (smooth areas) intermixed with mineral matter dominated by clay minerals (kaolinite). (b) Weathered Murphysboro coal sample showing a residual layer of clay minerals (upper section) and coal macerals (lower section). (c) Schwertmannite, the chief minerals found in the uppermost AMD sediment layer with morphology resembling a coral like structure. (d), (e), and (f) Goethite, the dominant mineral in the Fe-rich layer of the AMD sediments, forms aggregates that completely covered detrital particulates. Formation of these coatings could have further protected detrital particulates for dissolution. (g) and (h) Detrital clay minerals, which in the lower section of Si-Alrich layer of the AMD sediments are not coated by Fe-precipitates. 

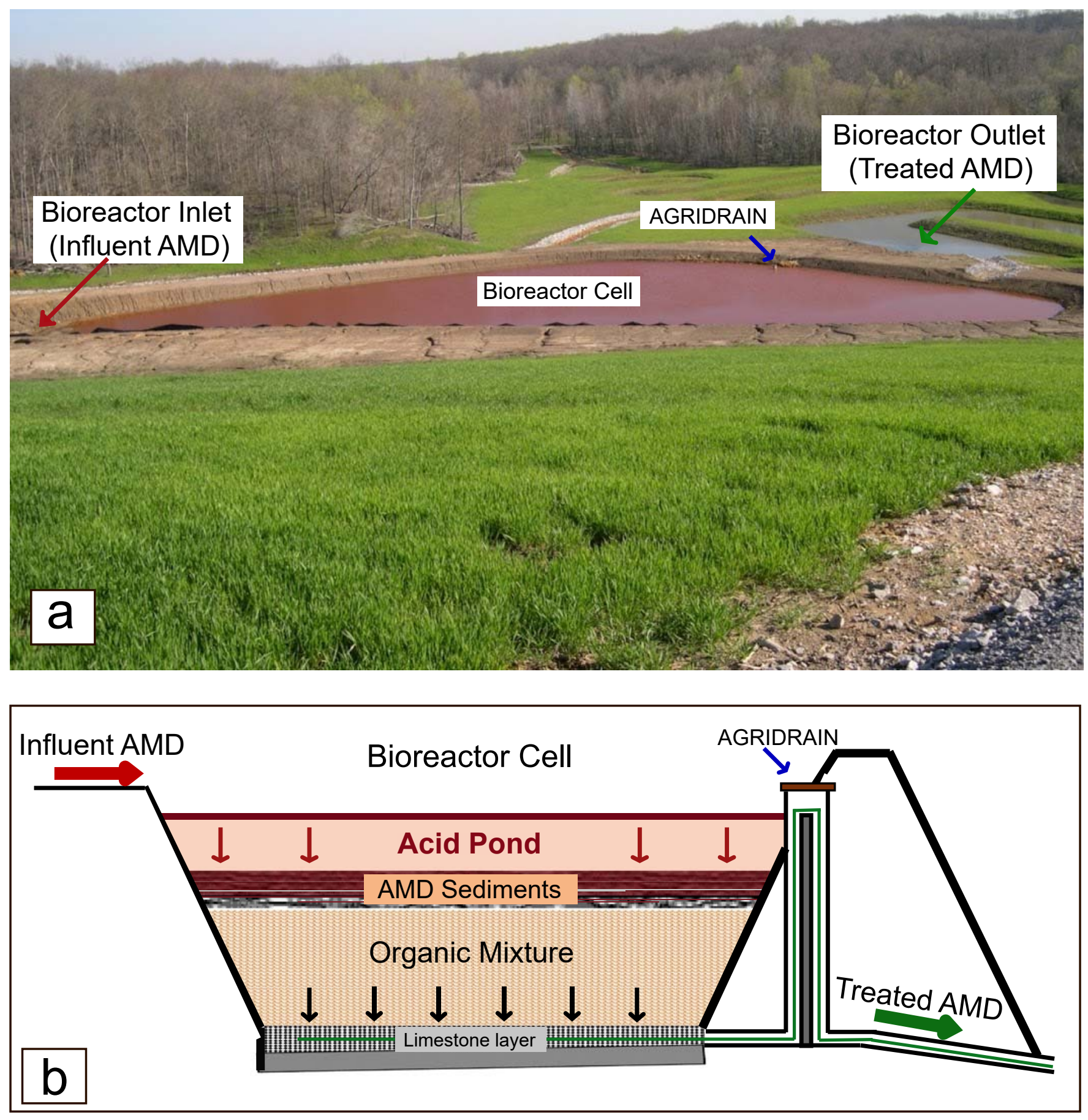

Figure 1: 

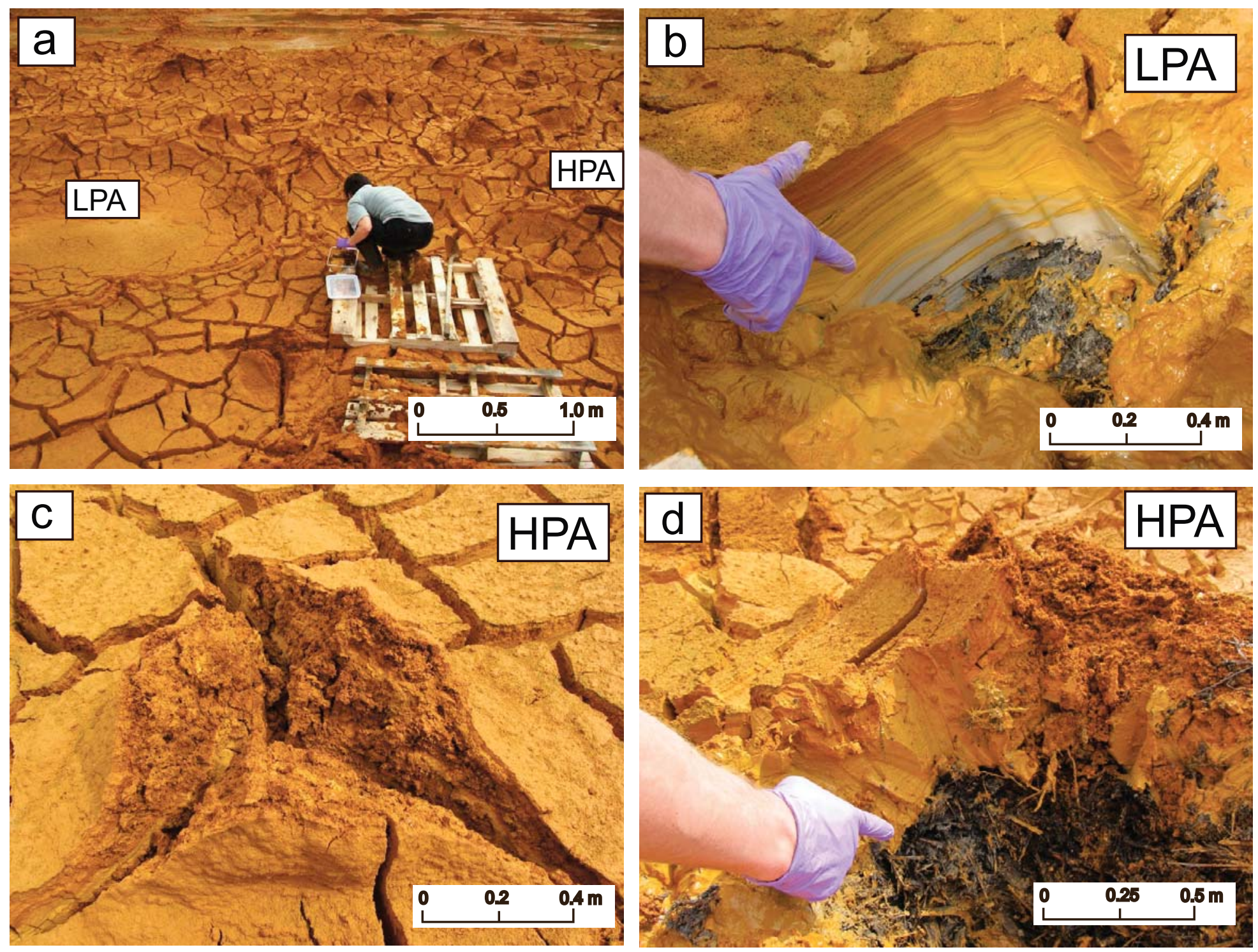

Figure 2: 


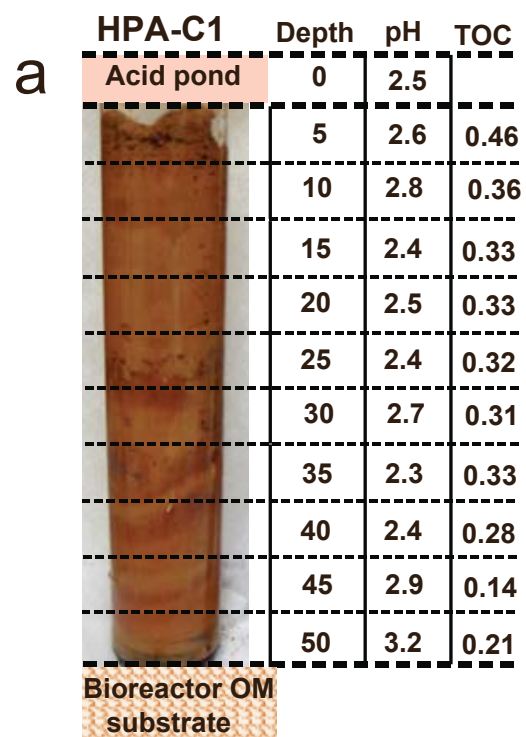

LPA-C4 Depth pH TOC

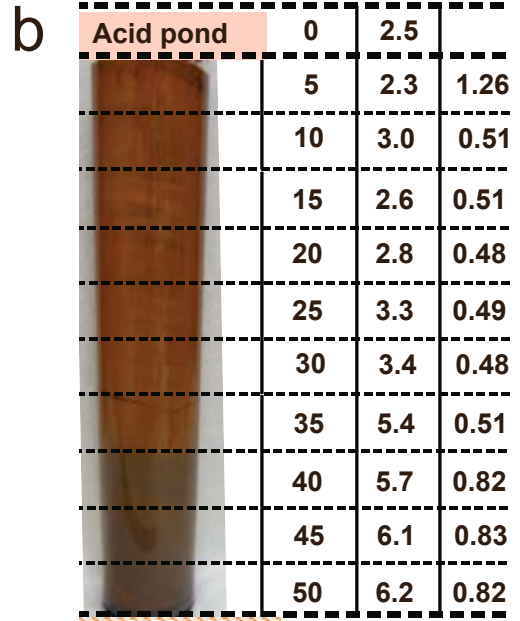
Bioreactor OM

substrate

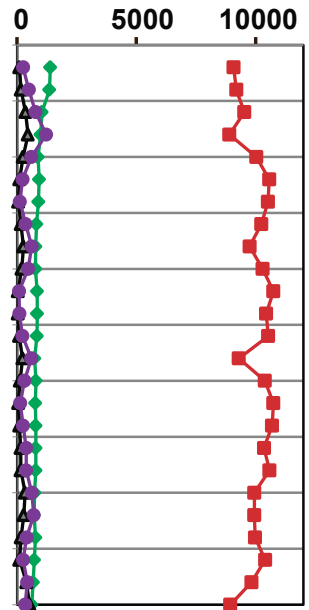

$\mathrm{Fe}_{\text {Тот }}(\mathrm{mM} / \mathrm{kg}) \mathrm{S}_{\text {тот }}(\mathrm{mM} / \mathrm{kg})$ $\mathrm{Al}_{\text {тот }}(\mathrm{mM} / \mathrm{kg}) \quad \mathrm{Si}_{\text {Tот }}(\mathrm{mM} / \mathrm{kg})$

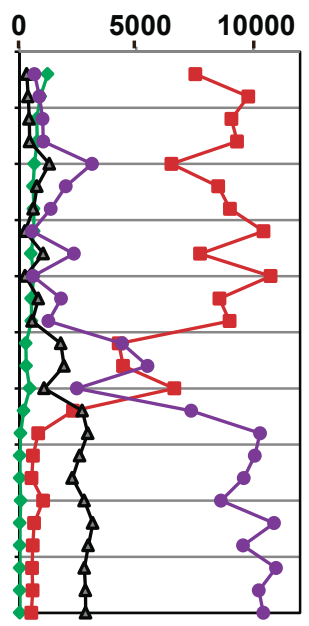

$\mathrm{Fe}_{\text {Tот }}(\mathrm{mM} / \mathrm{kg}) \mathrm{S}_{\text {TОт }}(\mathrm{mM} / \mathrm{kg})$ $\mathrm{Al}_{\text {Tот }}(\mathrm{mM} / \mathrm{kg}) \mathrm{Si}_{\text {Tот }}(\mathrm{mM} / \mathrm{kg})$
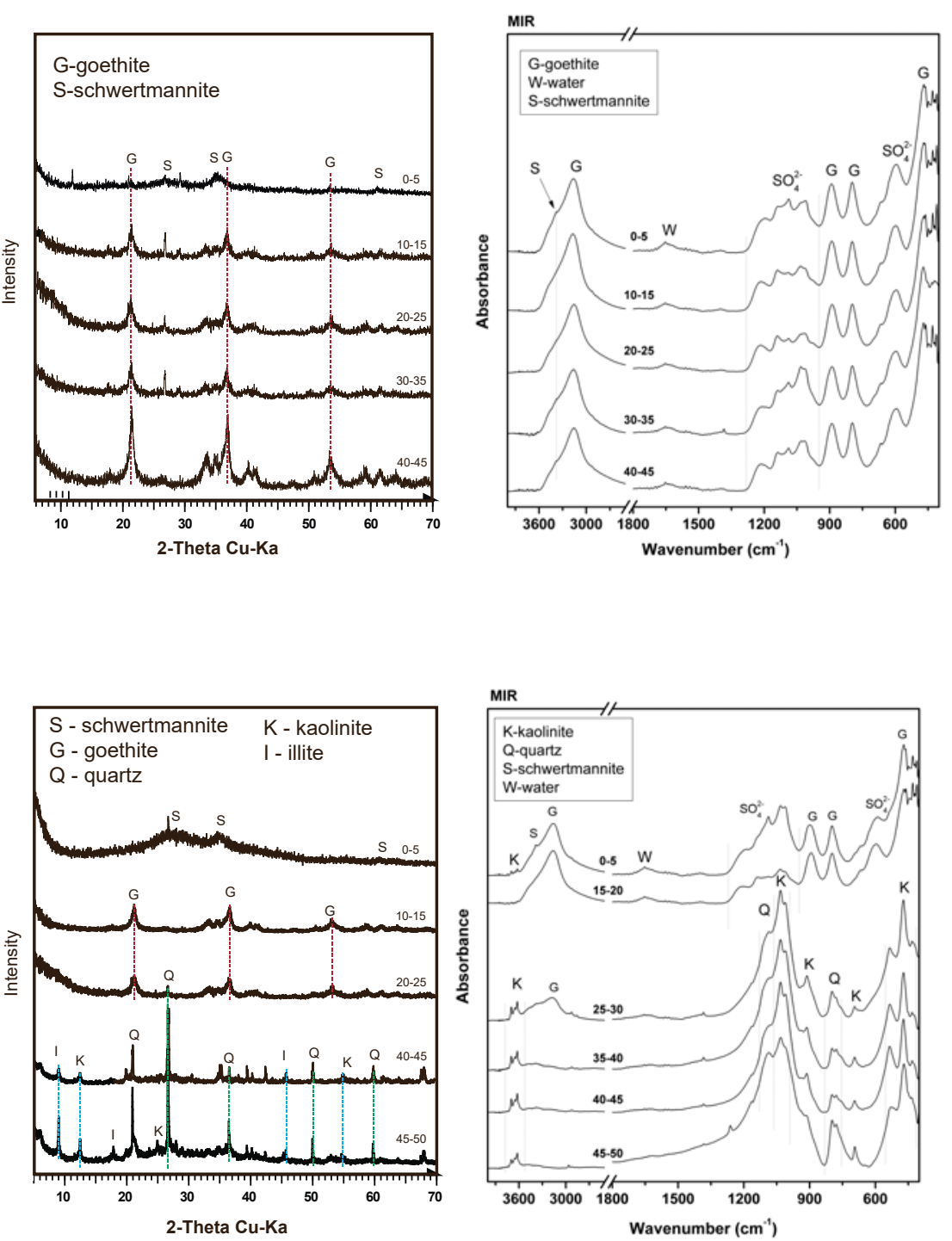

Figure 3: 
HPA-S3
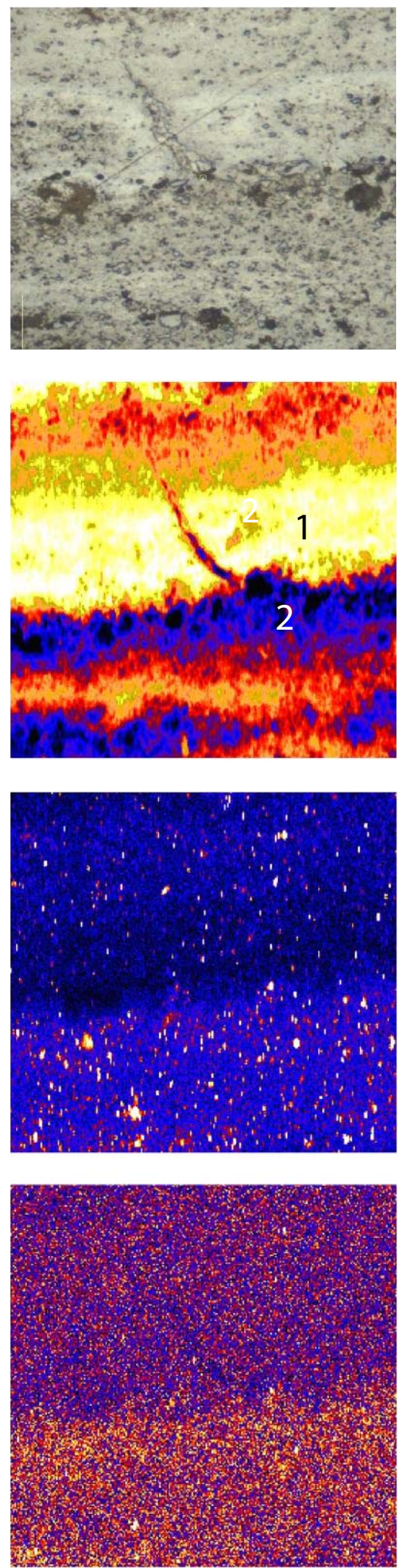

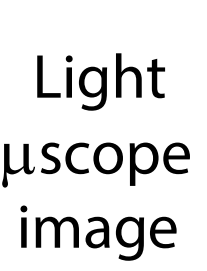

$\mathrm{Fe}$

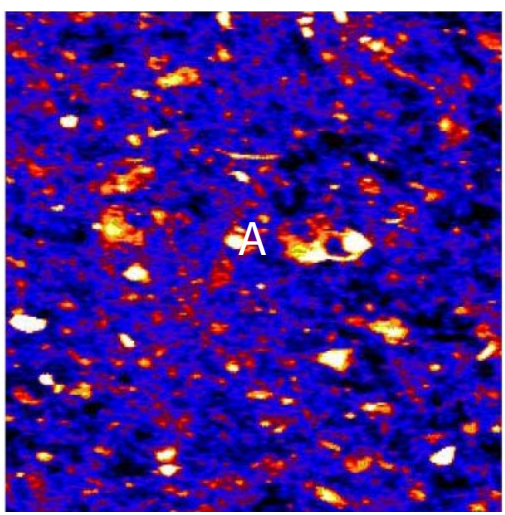

$\mathrm{Zr}$
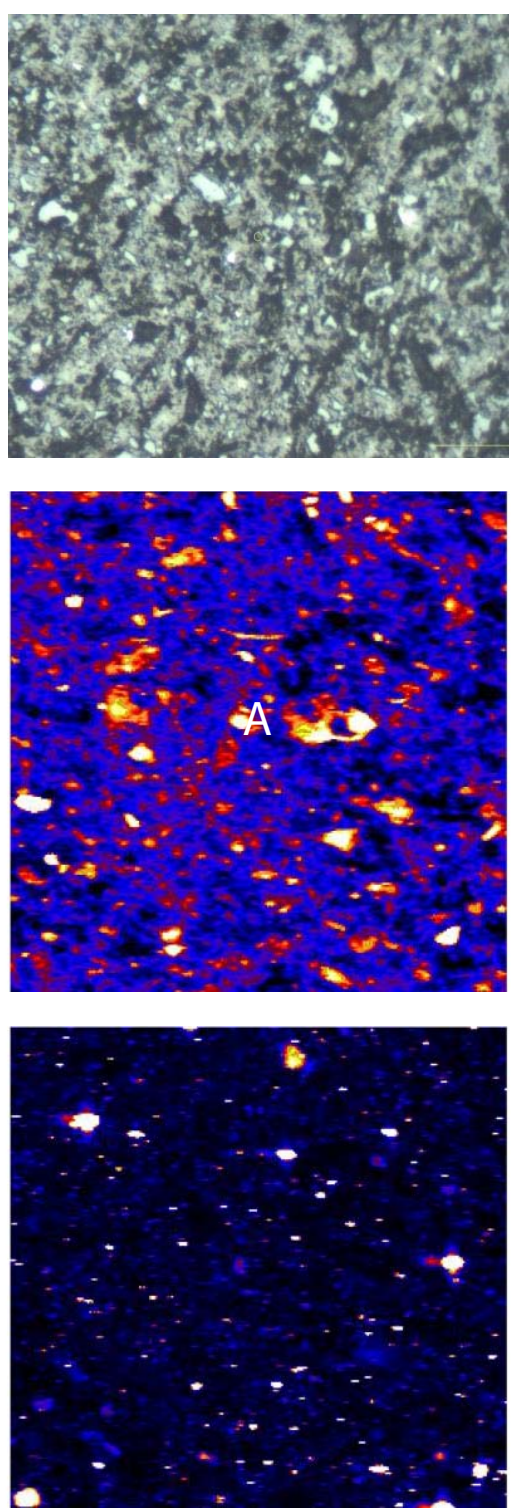

Ga $\max$
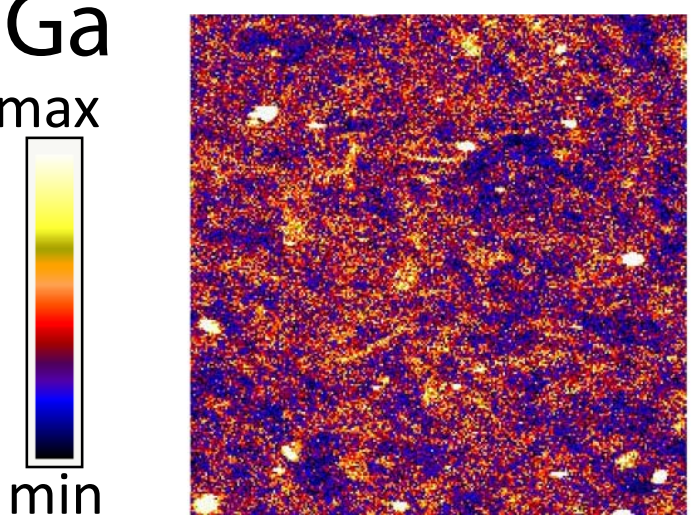

Figure 4: 


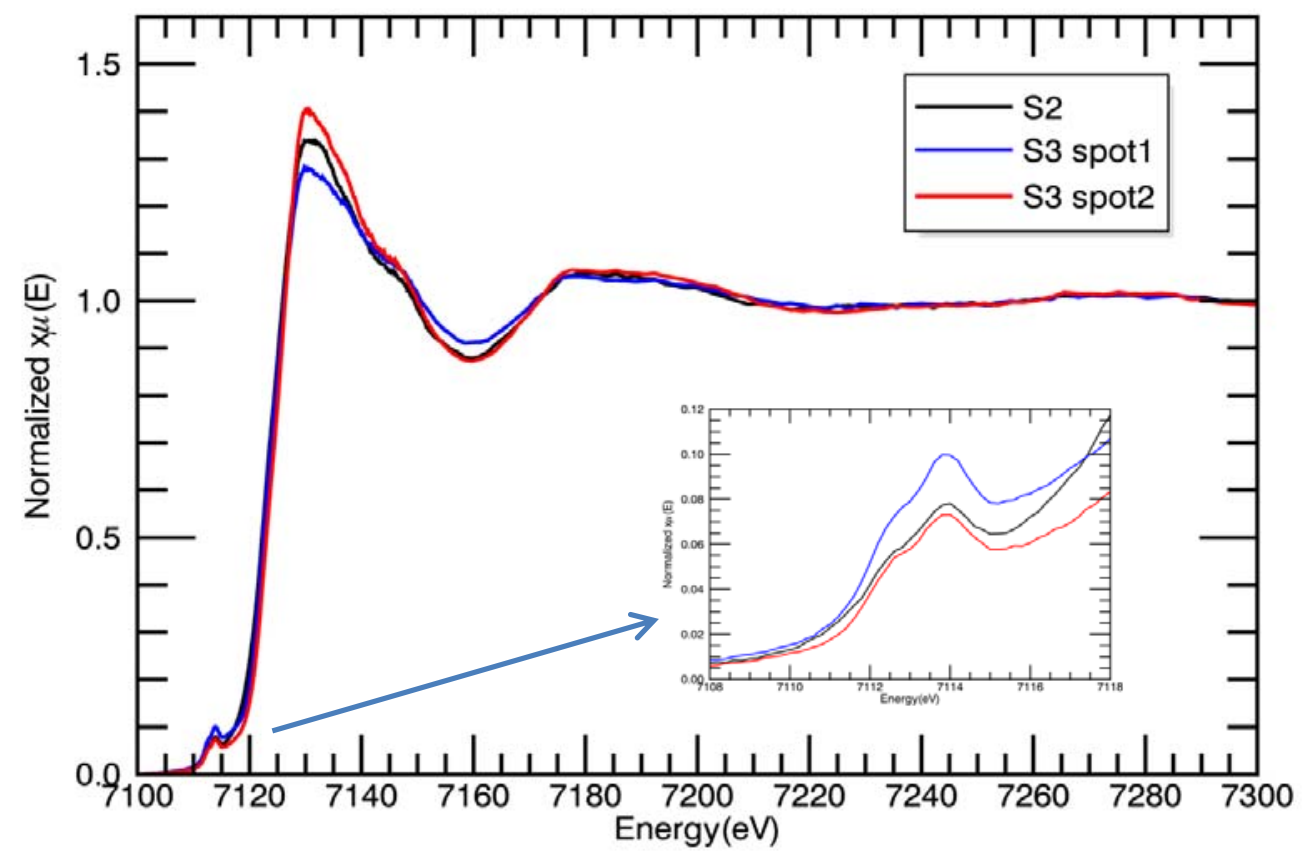

Figure 5: 

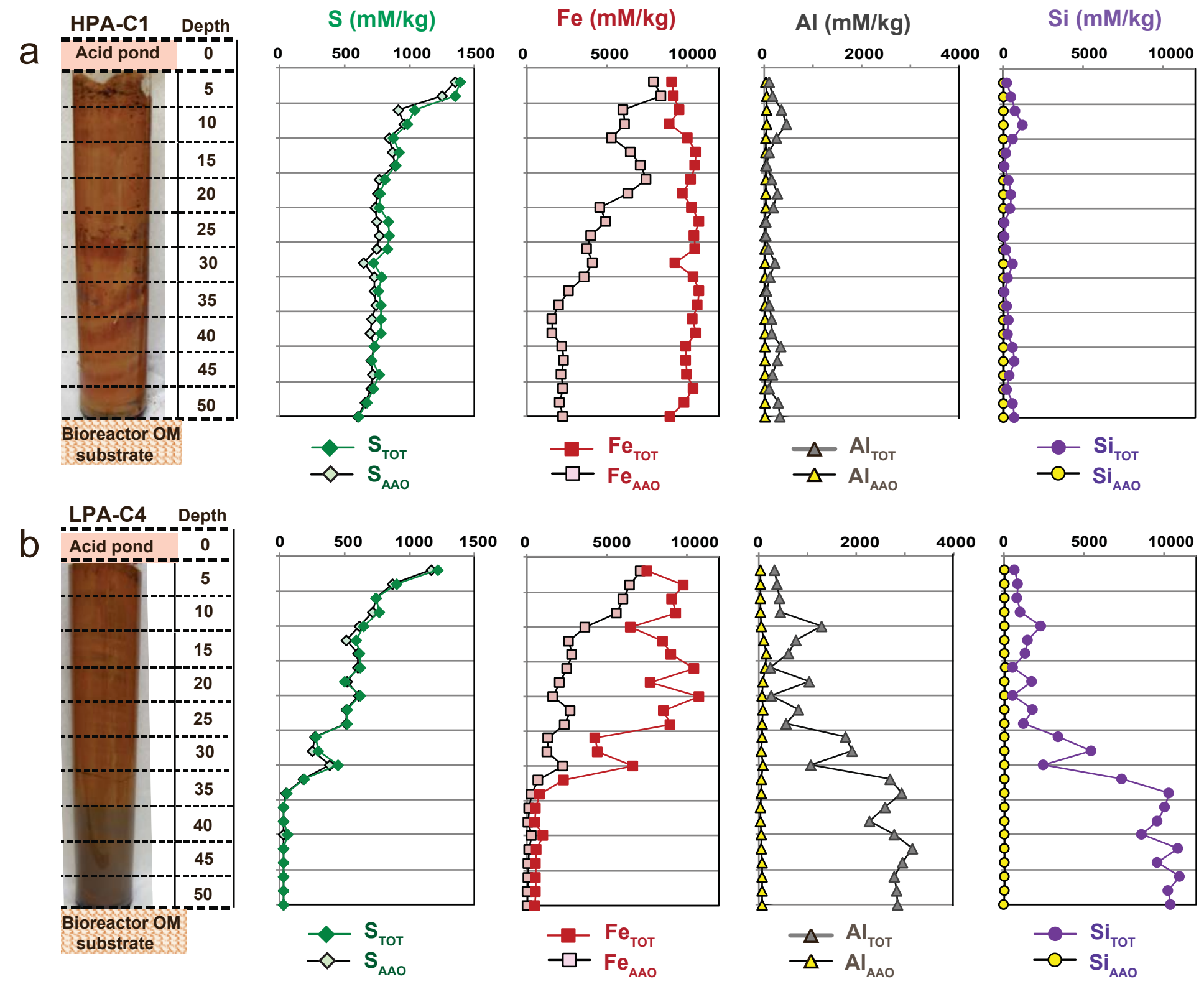

Figure 6: 

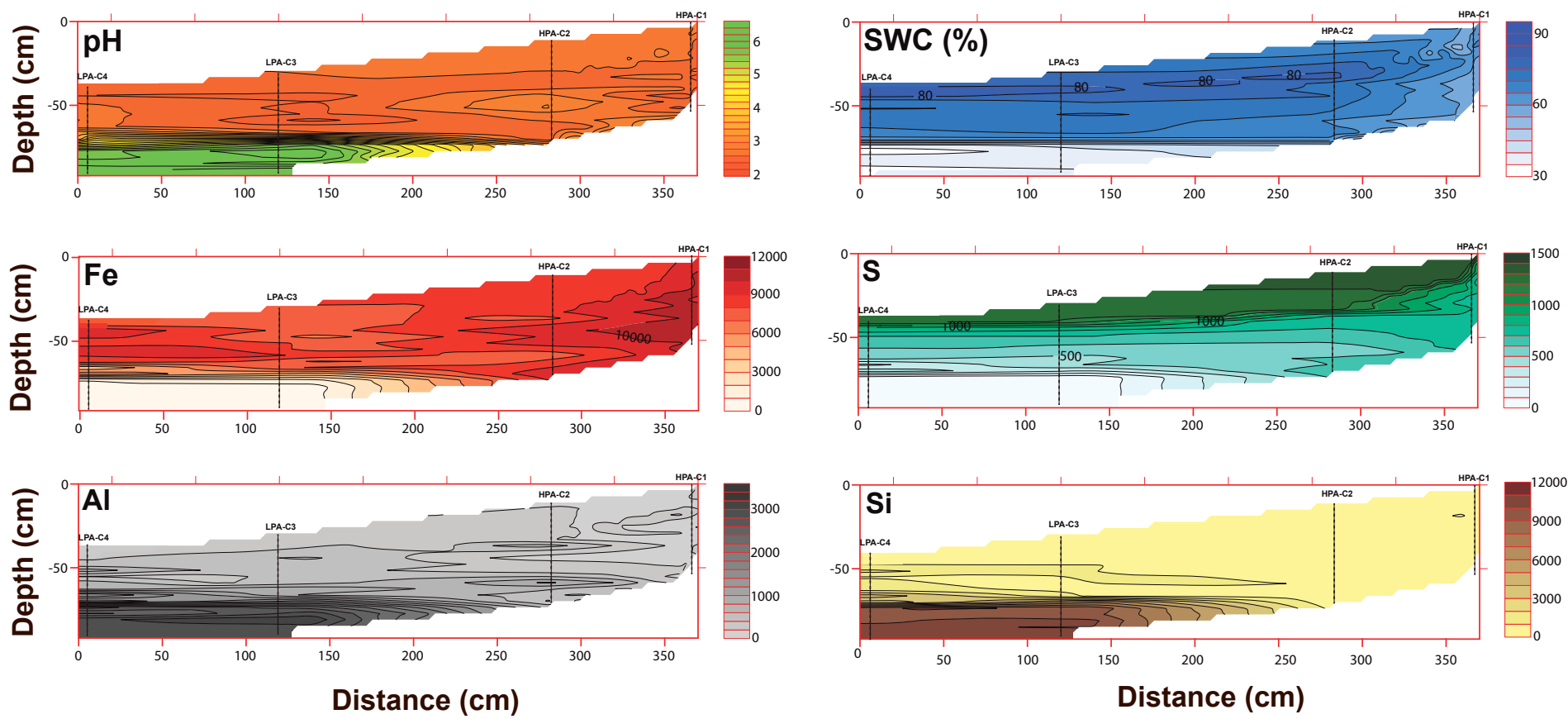

\section{Figure 7:}




\section{Bacterial Classes}

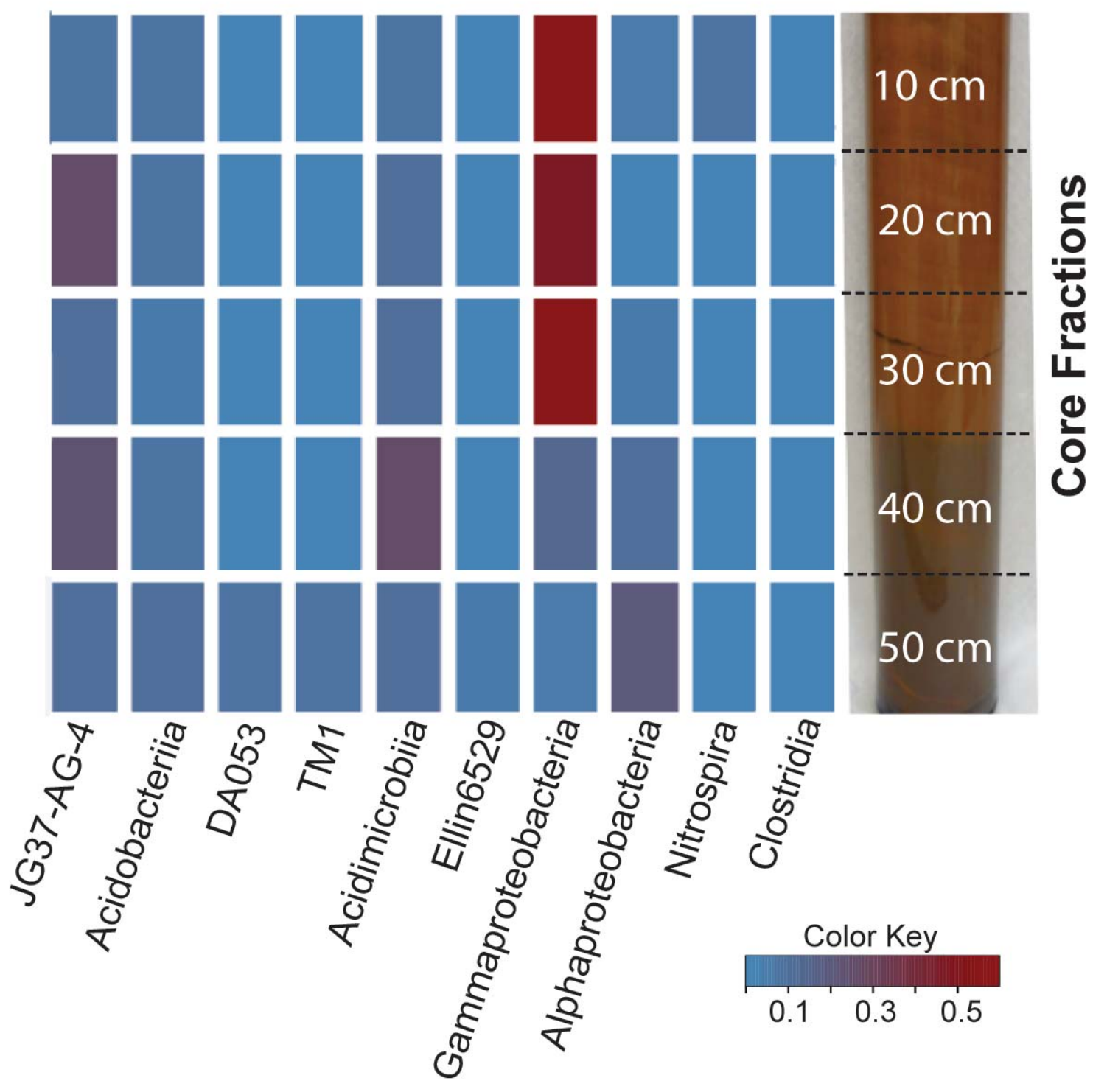

Figure 8: 

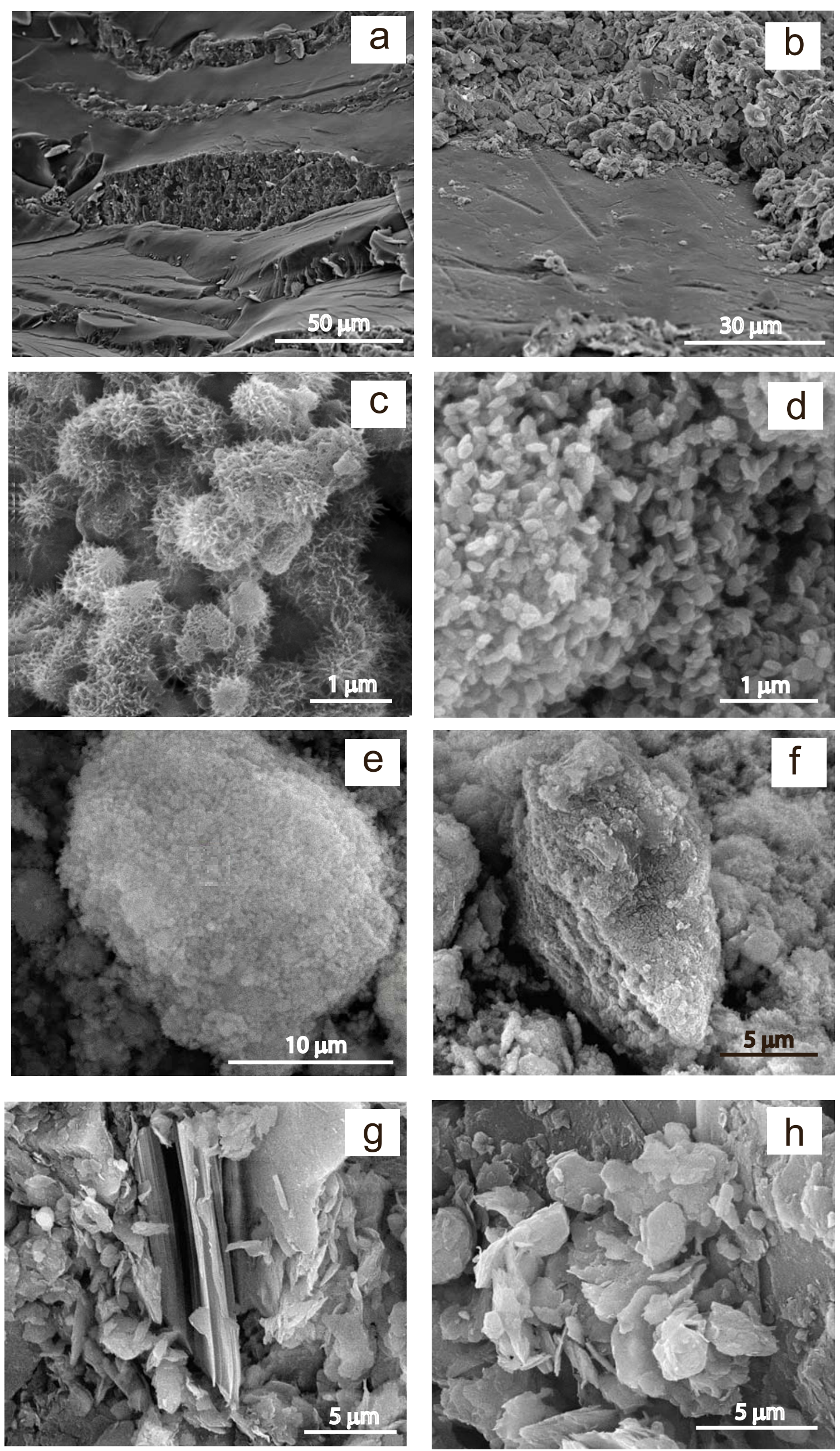

Figure 9: 

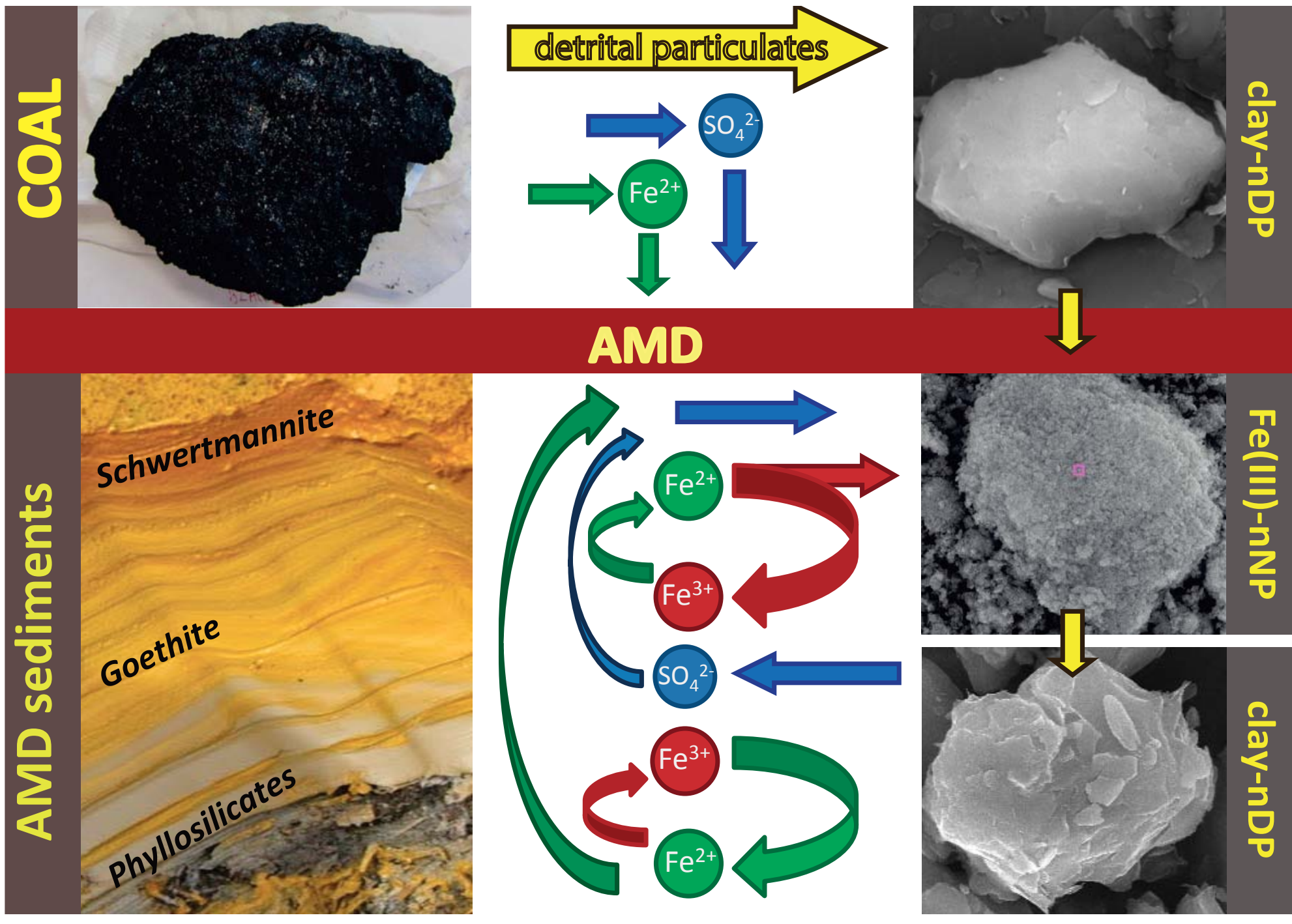

\section{AMD}
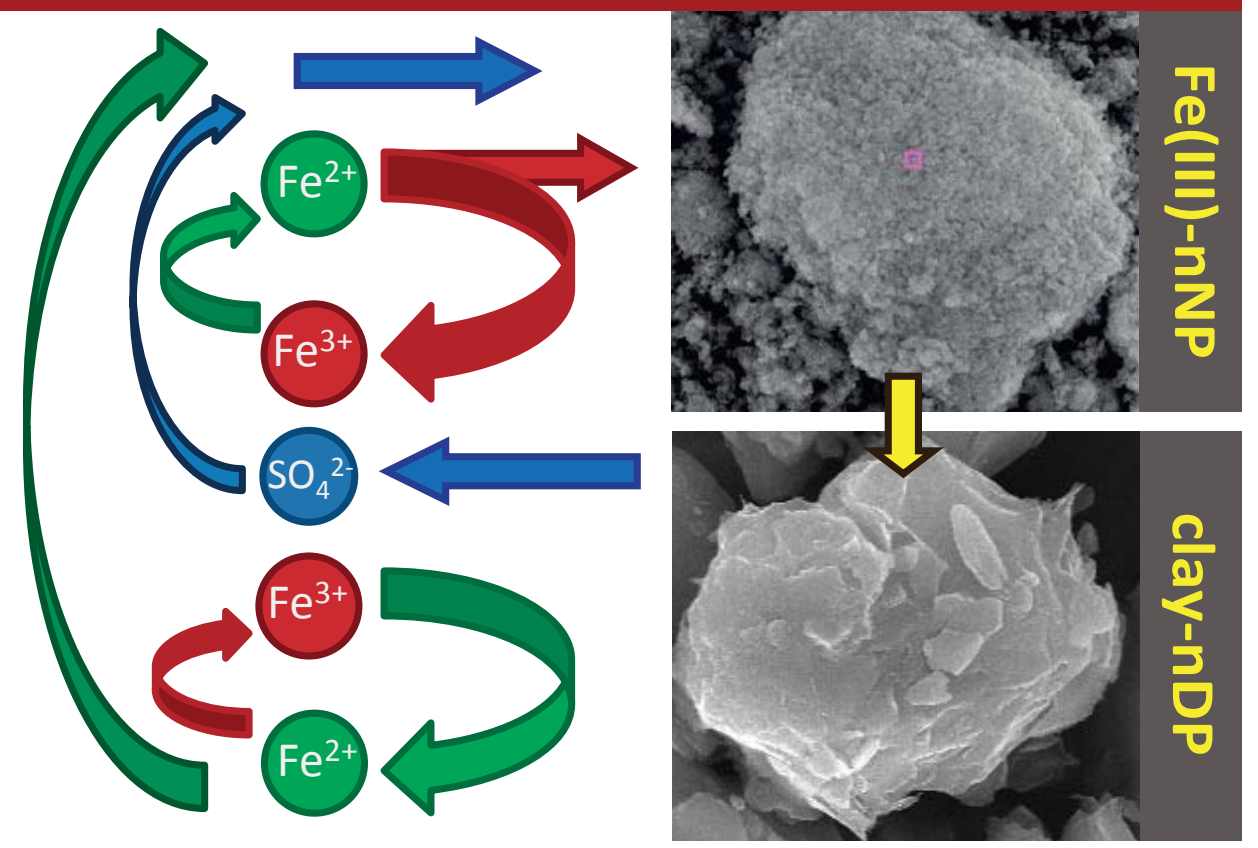

Graphical abstract:

Detrital nano- and micron-scale particles (dNP) originated from the weathering of coal waste represent a significant fraction of coal mine AMD contaminant load and play an important role in both sequestration and remobilization of neoformed nano- and micro-scale particles (nNP). 